KATARZYNA JAMROZIK

Instytut Informacji Naukowej i Bibliotekoznawstwa

Uniwersytetu Wrocławskiego

e-mail: katarzyna.jamrozik@uwr.edu.pl

MAŁGORZATA KORCZYŃSKA-DERKACZ

Instytut Informacji Naukowej i Bibliotekoznawstwa

Uniwersytetu Wrocławskiego

e-mail: malgorzata.derkacz@uwr.edu.pl

\title{
PROBLEMATYKA PRASOZNAWCZA NA ŁAMACH WYBRANYCH POLSKICH CZASOPISM BIBLIOLOGICZNYCH
}

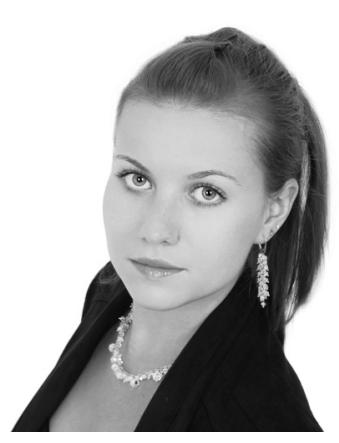

Katarzyna Jamrozik, magister informacji naukowej i bibliotekoznawstwa, doktorantka w Instytucie Informacji Naukowej i Bibliotekoznawstwa Uniwersytetu Wrocławskiego. Zainteresowania naukowe: jednodniówki, historia prasy sportowej, architektura informacji, eksploracja danych, funkcjonalność stron internetowych.

Małgorzata Korczyńska-Derkacz, dr hab., profesor w Instytucie Informacji Naukowej i Bibliotekoznawstwa Uniwersytetu Wrocławskiego; zainteresowania naukowe: kultura książki i bibliotek XIX i XX w.; bibliologia; prasoznawstwo; historia mediów i społecznego komunikowania, cenzura i manipulacja informacją; autorka książek: Państwowy Instytut Ksiażki (1946-1949) i jego rola w rozwoju bibliologii, bibliotekarstwa $i$ kultury ksią̇ki w Polsce (Wrocław 2011), Kronika Państwowego Instytutu Ksiązki (1945-1949). Wstęp, przypisy i opracowanie Małgorzata Korczyńska-Derkacz (Warszawa 2015).

SŁOWA KLUCZOWE: Prasoznawstwo. Bibliologia. „Bibliotekoznawstwo”. „Studia o Książce i Informacji”. „Studia o Książce”. „Roczniki Biblioteczne”. „Z badań nad Polskimi Księgozbio- 


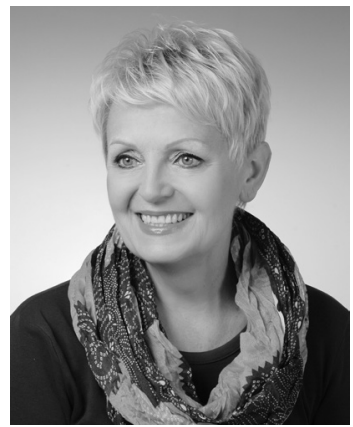

rami Historycznymi”. „Z Badań nad Książką i Księgozbiorami Historycznymi”. „Rocznik Naukowo-Dydaktyczny. Prace Bibliotekoznawcze”. .,Annales Universitatis Paedagogicae Cracoviensis Studia ad Bibliothecarum Scientiam Pertinentia”. „Kieleckie Studia Bibliologiczne”. „Studia Bibliologiczne Akademii Świętokrzyskiej”. „Rocznik Bibliologiczno-Prasoznawczy”. „Toruńskie Studia Bibliologiczne".

ABSTRAKT: Teza/cel artykułu - Wspólny rodowód bibliologii i prasoznawstwa oraz podobieństwa w zakresie przedmiotu badań, stosowanej metodologii, celów badań i miejsca w klasyfikacji nauk powodują jednoczesne prezentowanie tematyki obu tych dyscyplin w czasopismach o charakterze bibliologicznym. Celem artykułu było zbadanie obecności tematyki prasoznawczej w czasopismach wydawanych przez instytuty kształcące pracowników książki we Wrocławiu, w Warszawie, w Krakowie, w Kielcach, w Toruniu. Analizie poddano siedem tytułów i ich kontynuacje: seria „Bibliotekoznawstwo” (kontynuacja: „Studia o Książce i Informacji”), "Studia o Książce”, , Roczniki Biblioteczne”, ,Z badań nad Polskimi Księgozbiorami Historycznymi” (kontynuacja: „Z Badań nad Książką i Księgozbiorami Historycznymi”), „Rocznik Naukowo-Dydaktyczny. Prace Bibliotekoznawcze” (kontynuacja: „Annales Universitatis Paedagogicae Cracoviensis Studia ad Bibliothecarum Scientiam Pertinentia”), „Kieleckie Studia Bibliologiczne” (kontynuacje: „Studia Bibliologiczne Akademii Świętokrzyskiej”, „Rocznik Bibliologiczno-Prasoznawczy") oraz „Toruńskie Studia Bibliologiczne”. Metoda badań - wykorzystana została metoda analizy ilościowej, gdzie jednostką obliczeniową był artykuł (nie uwzględniano recenzji, przeglądów i polemik) o tematyce prasoznawczej, opublikowany na łamach wybranego czasopisma bibliologicznego. Wyniki i wnioski - badanie wykazało, iż tylko $14 \%$ wszystkich opublikowanych artykułów naukowych porusza problematykę prasoznawczą. Potwierdziło też znaczne rozproszenie artykułów naukowych.

\section{BIBLIOLOGIA I PRASOZNAWSTWO - DWIE DYSCYPLINY HUMANISTYCZNE}

„Cóż to jest nauka o prasie? - pytał w 1938 r. Boris Mirkine-Guetzévitch, dyrektor paryskiego Institut de Science de la Presse i sam odpowiadał na to pytanie: to „Nowy zespół wiadomości i metod, zastosowanych do badania wielkiego fenomenu społecznego, fenomenu złożonego, o wielu aspektach. Prasa rejestruje wydarzenia. Jest ona źródłem wiedzy historycznej, podległym jako takie regułom krytyki historycznej. Uczestniczy w tworzeniu opinii, bierze aktywny udział w walce interesów, idei i ludzi. Równie silnie wiąże się $\mathrm{z}$ rozwojem prawa. Istnieje $\mathrm{w}$ rozmaitych systemach prawnych. (...) jest wielkim przedsiębiorstwem przemysłowym i komercyjnym. Druk, papier, sprzedaż, ogłoszenia, wszystko to wiąże się z problemami ekonomicznymi, finansowymi, prawnymi, socjologicznymi" (cyt. za: Golka, 1969, s. 10). Dokumentowanie prawa do samodzielnego istnienia nauki odbywa się zawsze przez określenie przedmiotu badań, metod badawczych, miejsca w klasyfikacji wiedzy. W przypadku prasoznawstwa 
zjawisko to zaczęto obserwować w Polsce w połowie XX w. Początkowo w polu zainteresowania znalazła się prasa postrzegana jako źródło do badań historycznych, społecznych, politycznych, ekonomicznych, kulturowych. Z czasem zaczęto interesować się nią samą (gazety i czasopisma), jej twórcami (dziennikarze i wydawcy), metodami ich pracy oraz jej wytworami, zawartością i treścia, procesami ich rozpowszechniania, warunkami oddziaływania oraz ich skutkami, organizacją redakcji. Stąd już tylko krok do zainteresowania się czytelnikami (publiczność medialna), ich preferencjami, ale i wpływami, którym - za pośrednictwem prasy i innych środków masowej komunikacji - ulegają (opinia publiczna). Jak pisał Walery Pisarek: „Rozważaniom o przedmiocie i charakterze prasoznawstwa towarzyszyła często refleksja nad jego wewnętrznym zróżnicowaniem, nad zapleczem metodologicznym i użytecznością w praktyce dziennikarskiej, redakcyjnej i wydawniczej. [...] W atmosferze sporów i dyskusji konstytuowało się to, co po polsku nazywamy do dziś prasoznawstwem, a co w innych krajach nazywane bywa nauką lub wiedzą o prasie, radiu i telewizji, o komunikowaniu masowym, o komunikowaniu publicznym, o komunikowaniu zbiorowym, o komunikacji społecznej, o mediach masowych, o dziennikarstwie" (Pisarek, 1984, s. 6). Sam autor, przez prasoznawstwo rozumiał "dziedzinę nauki obejmującą wszystkie elementy, fazy i aspekty komunikowania masowego za pomocą środków o charakterze periodycznym lub ciągłym" (Pisarek, 1984, s. 6).

Czasopisma i gazety pełnią funkcje podobne do funkcji książki. O podobieństwach mówić możemy na etapie ich wytwarzania, obiegu i odbioru społecznego. Liczne analogie z procesami bibliologicznymi widoczne są na płaszczyźnie nauki o drukarstwie oraz wiedzy o masowym komunikowaniu. Warto przypomnieć tu teoretyczne rozważania Paula Otleta, który kierując się potrzebami pracy nad bibliografią światową, w Traktacie o dokumentacji z 1934 r. mówił o konieczności objęcia badaniem wszelkich dokumentów (książek, czasopism, wszelkich „scripta”), które miały się stać przedmiotem bibliologii, utożsamianej wówczas z dokumentologią. Jak pisał Krzysztof Migoń Traktat Otleta „Poszerzył pole badań bibliologicznych, umieszczając w nim wszelkie formy dokumentów, rozbudował i teorię, i zastosowania bibliologii. Utorował w ten sposób drogę do bibliologii dzisiejszej jako nauki o komunikacji piśmiennej" (Migoń, 2005, s. 53), która - dodajmy - jest jedną z form komunikacji społecznej. Odwołując się do autorytetów, przytoczmy jeszcze słowa Karola Głombiowskiego, który w 1980 r. napisał: „,...] równorzędną rolę odgrywa wytwarzanie i rozpowszechnianie komunikatów, jak też ich recepcja, a obok twórców komunikatów nie mniejsze znaczenie dla istoty procesu posiadają ich odbiorcy" (Głombiowski, 1980, s. 13) - sformułowania autora dotyczyły wprawdzie książki - kategorii centralnej w badaniach bibliologicznych - ale odnieść je możemy także do gazet i czasopism, radia 
i telewizji, a nawet szerzej - do mediów elektronicznych. Twórca książki i jej czytelnik, nadawca i odbiorca komunikatu, to ludzie i związane z nimi instytucje, stanowiące istotne ogniwo całego procesu komunikacji społecznej/medialnej. Zbieżność zainteresowań bibliologii i prasoznawstwa jest tu wyraźnie widoczna.

Elementem określającym samodzielność dyscypliny jest także jej metodologia. Najbardziej charakterystyczną i rozpoznawalną metodą w badaniach prasoznawczych jest metoda historyczna oraz metoda analizy zawartości treści. Władysław Marek Kolasa w swojej rozprawie Historiografia prasy polskiej (do 1918 roku) (Kolasa, 2013, s. 6-9, 15-64) wskazał, że prasoznawstwo może korzystać i korzysta z metod naukoznawczych, zwłaszcza z naukometrii i bibliometrii - obie metody z powodzeniem stosowane są $\mathrm{w}$ bibliologii. Prasoznawstwo wykorzystuje także metody i techniki zapożyczone z socjologii, psychologii, ekonomii, prawa czy z językoznawstwa. Korzysta $\mathrm{z}$ analiz statystycznych. Podobnie postępuje się w bibliologii.

Interesująco wypada analiza dróg rozwoju bibliologii i prasoznawstwa, co pozwala na sformułowanie wniosków o ich wspólnym rodowodzie. Nazwiska pierwszych polskich badaczy, zainteresowanych dokumentowaniem prasy i uznaniem jej za cenne źródło historyczne, są wymieniane wśród prekursorów bibliologii - mowa o Pawle Jarkowskim i jego wykładach z bibliografii początkowo w Gimnazjum Wołyńskim, a następnie po jego przemianowaniu w 1818 r. - w Liceum Krzemienieckim, Feliksie Bentkowskim i jego bibliografii literatury uwzględniającej także czasopisma (dwutomowa Historia literatury polskiej wystawiona w spisie dzieł drukiem ogłoszonych z 1814 r.), o Jerzym Samuelu Bandtkiem (Wiadomość krótka o gazetach polskich, opublikowana w „Roczniku Towarzystwa Naukowego Krakowskiego" 1819, t. 4, s. 205-224), o bibliograficznych pracach Adama Tomasza Chłędowskiego, o Joachimie Lelewelu (Bibliograficznych ksiag dwoje, Wilno t. 1-2; 1823-1826) i Aleksandrze Bohatkiewiczu (bibliografia powszechna), oraz o pracach Józefa Muczkowskiego, Karola Szajnochy i Karola Estreichera. To właśnie Estreicher zestawił pierwszy naukowy spis prasy w Polsce i zamieścił go w tomie Bibliografii polskiej wydanej w 1870 r. ${ }^{1}$. Rok później spis ten pojawił się $\mathrm{w}$ formie broszury zatytułowanej 1400 pism periodycznych i zbiorowych. Zestawienie to, choć jeszcze niedoskonałe i poddane krytyce z powodu nieostrych kryteriów typologicznych, stało się punktem wyjścia do pierwszych rozważań statystycznych na temat ruchu wydawniczego, które w 1886 r. opublikował Stanisław Czarnowski. Uzupełnił je w 1928 r. Stanisław Jarkowski. Pierwsze prace prasoznawcze, podobnie jak badania nad książka, pojawiły się na pograniczu badań nad historią li-

${ }^{1}$ Jedną z najwcześniejszych prac dokumentujących zawartość czasopisma był spis zawartości „Journal de Sawants", wydany w Amsterdamie w 1683 r. Niemiecki uczony przełomu XVII i XVIII w. Christian Juncker był autorem zestawienia 68 tytułów czasopism, w którym traktuje czasopismo naukowe jak część uniwersum świata książek. Więcej zob. (Żbikowska-Migoń, 2002). 
teratury. Tak było w przypadku wymienionych wyżej prac, tak też było u Konstantego Majeranowskiego w pracy Wiadomość historyczno-krytyczna o pismach periodycznych w Polszcze z 1826 r. (Flora Polska, czyli Rozrywki Przyjemne i Pożyteczne,1826, t. 5, s. 34-64; t. 6, s. 37-61; Flora Polska, czyli Rozrywki Przyjemne i Pożyteczne, 1827, t. 8, cz. 1, s. 37-44; Motyl, 1829, nr 1, 4, 8, 10; polemika Rozmaitości (Lwów) 1827, nr 3); większe opracowanie omawiające genezę prasy na szerokim tle napisał w 1861 r. Franciszek Sobieszczański (Sobieszczański, 1861).

Tyle wspólny rodowód. Należy dodać, że obie nauki należą do grupy nauk humanistycznych, społecznych, w obu możemy szukać pogranicza badawczego z wieloma innymi dyscyplinami naukowymi: prawem, ekonomia, socjologia, etyka, językoznawstwem, historią psychologią społeczna, antropologią kulturową. Potwierdzają to i przedmiot badań, i stosowana w nich metodologia. Prasa wraz z innymi mediami, jej instytucje i użytkownicy od kilku już lat sytuowana jest w obrębie medioznawstwa, odrębnej dziedziny, posługującej się empirycznymi metodami nauk społecznych oraz metodami specyficznymi, jakimi są analiza zawartości treści i sondażowe badania odbiorców, a wszystko to z punktu widzenia teorii społeczeństwa informacyjnego/sieciowego/medialnego. O wzajemnych relacjach bibliologii i medioznawstwa wypowiadał się Krzysztof Migoń podkreślając, że decyduje o tym obiekt ich badań, wspólne - w pewnych zakresach zadania i metody (Migoń, 2002).

Zasygnalizowane już wyżej kierunki badań prasoznawczych z biegiem lat ulegały zmianom (poszerzeniu) wynikającym z rozwoju dyscypliny, jej zinstytucjonalizowania, subiektywnych zainteresowań badaczy, dostępu do źródeł. Wskazując główne tendencje w tym zakresie można powiedzieć, że do najchętniej podejmowanych należą badania historycznoprasowe ${ }^{2}$, w szczególności dotyczące prasy dawnej (do 1864 r.), prasy okresu popowstaniowego (1864-1918), okresu międzywojennego, okresu okupacji hitlerowskiej (prasa konspiracyjna), prasy lat 1945-1989 oraz zagadnień transformacji mediów po 1989 r. Badania szczegółowe koncentrują się wokół konkretnych tytułów, modelu prasy z punktu widzenia jej przeznaczenia i typologii (np. prasa dla ludu, prasa katolicka, prasa religijna, prasa fachowa, prasa ugrupowań politycznych, prasa studencka...,). Rozwijają się badania nad rynkiem prasowym, nad twórcami prasy (dziennikarza$\mathrm{mi}$, wydawcami, ilustratorami), nad odbiorcami i społeczną funkcją prasy. Nowa, elektroniczna postać czasopisma także wzbudziła zainteresowanie badaczy. Autorzy zajmują się teorią i praktyką środków masowego komunikowania, a postępujący rozwój medioznawstwa wpisuje w krąg ich

\footnotetext{
2 Szczegółowo omówił tę kwestię W. M. Kolasa (2013). Na temat przedmiotu badań prasoznawstwa wypowiadali się m.in. I. Tetelowska (1965, s. 11-14), M. Kafel (1966, s. 88-102), S. Dziki (1984), W. Pisarek (2008, s. 182-209).
} 
zainteresowań - poza dziennikarstwem drukowanym - dziennikarstwo medialne: radiowe, telewizyjne, internetowe.

Celem naszych rozważań nie jest szczegółowe śledzenie rozwoju i dokonań prasoznawstwa, jest nim natomiast sprawdzenie, czy wykazana wyżej jego bliskość z bibliologią sprawia, iż prace dotyczące wymienionych wyżej zagadnień prasoznawczych (i medialnych) są obecne na łamach czasopism wydawanych przez instytuty kształcące pracowników książki, tj. Instytut Informacji Naukowej i Bibliotekoznawstwa Uniwersytetu Wrocławskiego (seria „Bibliotekoznawstwo”, „Studia o Książce”, „Roczniki Biblioteczne"), Instytut Nauk o Informacji Uniwersytetu Pedagogicznego w Krakowie („,Rocznik Naukowo-Dydaktyczny. Prace Bibliotekoznawcze”), Instytut Informacji Naukowej i Bibliologii UMK („,Toruńskie Studia Bibliologiczne"), Instytut Dziennikarstwa i Informacji Uniwersytetu Jana Kochanowskiego w Kielcach („,Kieleckie Studia Bibliologiczne”) oraz Instytut Informacji Naukowej i Studiów Bibliologicznych Uniwersytetu Warszawskiego („,Z badań nad Książką i Księgozbiorami Historycznymi”). Pod uwagę wzięto siedem tytułów czasopism (i ich kontynuacje), przyjmując założenie, że ich redakcja merytoryczna wywodzi się z danego instytutu, a wydawcą jest macierzysta uczelnia ${ }^{4}$.

Wykorzystana została metoda analizy ilościowej, gdzie jednostką obliczeniową był artykuł naukowy ${ }^{5}$ o tematyce prasoznawczej, opublikowany na łamach wybranego czasopisma.

\section{ZAGADNIENIA PRASOZNAWCZE NA ŁAMACH ANALIZOWANYCH TYTUŁÓW}

Najwcześniej, bo w 1955 r., w Instytucie Informacji Naukowej i Bibliotekoznawstwa Uniwersytetu Wrocławskiego (ówczesny Instytut Bibliotekoznawstwa) powołano rocznik „Bibliotekoznawstwo”, ukazujący się w ramach serii „Acta Universitatis Wratislaviensis”. W 2012 r. nastąpiła zmiana tytułu czasopisma na „Studia o Książce i Informacji”, co wiązało się również z poszerzeniem podejmowanej tematyki od teorii i praktyki bibliologii w stronę działalności edytorskiej i estetyki książki (Studia o Ksiażce i Informacji (dawniej: Bibliotekoznawstwo) [online]. [dostęp: 25.04.2017]. Dostępny w WWW: $<$ http://bibl.wuwr.pl >.). Do 2016 r. opublikowano 35 tomów, w tym 13 pozycji monograficznych (t. 6-18), które zostały wyłączone z analizy.

\footnotetext{
${ }^{3}$ Obecnie na Wydziale Dziennikarstwa, Informacji i Bibliologii UW.

${ }^{4}$ Przyjmując powyższe założenia - kryterium wydawcy - nie wzięto pod uwagę istotnych dla nauk bibliologicznych tytułów, m.in. „Przeglądu Bibliotecznego”, „Rocznika Biblioteki Narodowej”, „Ze Skarbca Kultury”, „Rocznika Biblioteki PAU i PAN w Krakowie”, „Studiów Kieleckich. Serii Bibliologiczno-Prasoznawczej"), a także czasopism, których założenia redakcyjne sytuują je w obrębie nauki o informacji („Zagadnienia Informacji Naukowej”, ,Infotezy”).

${ }^{5} \mathrm{~W}$ badaniach nie brano pod uwagę artykułów recenzyjnych, przeglądowych i polemik.
} 
Tabela 1

Czasopismo „Acta Universitatis Wratislaviensis. Seria: Bibliotekoznawstwo” wraz z kontynuacją „Studia o Książce i Informacji”" (1955-2016)

\begin{tabular}{|c|c|c|c|c|}
\hline Rok, tom & $\begin{array}{l}\text { Ogólna } \\
\text { liczba art. }\end{array}$ & $\begin{array}{l}\text { Liczba art. } \\
\text { prasozn. }\end{array}$ & Autor & Tytuł artykułu \\
\hline $\begin{array}{l}1955 \\
\text { t. } 1-1956, \text { t. } 2\end{array}$ & 7 & 0 & & \\
\hline 1962, t. 3 & 6 & 1 & Reiter Jan & ,Tygodnik Polski” w Opolu \\
\hline 1966, t. 4 & 5 & 0 & & \\
\hline 1968 , t. 5 & 5 & 1 & Kruczała Krystyna & $\begin{array}{l}\text { Książka polska wśród ludu górnoślą- } \\
\text { skiego w LL połowie XIX w. w świe- } \\
\text { tle dokumentacji prasowej }\end{array}$ \\
\hline 1995, t. 19 & 11 & 0 & & \\
\hline 1998, t. 21 & 10 & 1 & $\begin{array}{l}\text { Łaszewska-Radwań- } \\
\text { ska Beata Emilia }\end{array}$ & $\begin{array}{l}\text { „Przyjaciel dla Dzieci” Christiana Fe- } \\
\text { liksa Weissego. Zagadnienia autor- } \\
\text { stwa, przekładu i wydania polskiego }\end{array}$ \\
\hline 2000 , t. 23 & 10 & 1 & $\begin{array}{l}\text { Korczyńska-Der- } \\
\text { kacz Małgorzata }\end{array}$ & $\begin{array}{l}\text { "Rocznik Towarzystwa Warszawskie- } \\
\text { go...." }\end{array}$ \\
\hline \multirow[t]{2}{*}{2006 , t. 26} & \multirow[t]{2}{*}{12} & \multirow[t]{2}{*}{2} & $\begin{array}{l}\text { Korczyńska-Der- } \\
\text { kacz Małgorzata }\end{array}$ & $\begin{array}{l}\text { Informacja o nauce na łamach czasopi- } \\
\text { sma Zakładu Narodowego im. Osso- } \\
\text { lińskich we Lwowie (1828-1869) }\end{array}$ \\
\hline & & & Pękalska Marta & $\begin{array}{l}\text { "Pojezierze" - zapomniane wydaw- } \\
\text { nictwo regionalne }\end{array}$ \\
\hline \multirow[t]{2}{*}{2008 , t. 27} & \multirow[t]{2}{*}{9} & \multirow[t]{2}{*}{2} & Repucho Ewa & $\begin{array}{l}\text { Estetyka zaangażowana. Rola „Po- } \\
\text { ligrafiki” w podnoszeniu poziomu } \\
\text { estetycznego polskiej produkcji wy- } \\
\text { dawniczej w latach 1947-1956 }\end{array}$ \\
\hline & & & $\begin{array}{l}\text { Korczyńska-Der- } \\
\text { kacz Małgorzata }\end{array}$ & $\begin{array}{l}\text { Jednodniówka jako typ dokumentów } \\
\text { życia społecznego. Zarys problematy- } \\
\text { ki badawczej }\end{array}$ \\
\hline 2009, t. 28 & 16 & 0 & & \\
\hline 2010 , t. 29 & 8 & 1 & Ruszczak Olga & $\begin{array}{l}\text { Ukształtowanie graficzne czasopism } \\
\text { na Zakarpaciu w drugiej połowie XIX } \\
\text { i na początku XX w. }\end{array}$ \\
\hline $\begin{array}{l}2011, \text { t. } 30- \\
2013, \text { t. } 32 \\
\end{array}$ & 22 & 0 & & \\
\hline 2014, t. 33 & 7 & 1 & Kośny Leszek & $\begin{array}{l}\text { Stan badań nad polskimi czasopisma- } \\
\text { mi pszczelarskimi }\end{array}$ \\
\hline \multirow{2}{*}{2015 , t. 34} & \multirow{2}{*}{8} & \multirow{2}{*}{2} & Jamrozik Katarzyna & $\begin{array}{l}\text { Żydowskie jednodniówki sportowe } \\
\text { z okresu międzywojennego (ze zbio- } \\
\text { rów CBN Polona). }\end{array}$ \\
\hline & & & Łach Anna & $\begin{array}{l}\text { Mediatyzacja nauki w prasie pol- } \\
\text { skiej (1975) - popularyzacja czy no- } \\
\text { winkarstwo? }\end{array}$ \\
\hline 2016 , t. 35 & 10 & 0 & & \\
\hline łącznie & 146 & 12 & & \\
\hline
\end{tabular}

Źródło: obliczenia własne na podstawie analizy zawartości czasopism: „Acta Universitatis Wratislaviensis. Seria: „Bibliotekoznawstwo” oraz „Studia o Książce i Informacji” (1955-2016). 
Na łamach czasopisma opublikowano 146 artykułów problemowych, w tym zaledwie 12 poruszających zagadnienia prasoznawcze, co stanowi $8,22 \%$. Dwa artykuły dotyczyły kwestii graficzno-edytorskich czasopism (Ewy Repucho i Olgi Ruszczak), również dwukrotnie podjęto problematykę jednodniówek jako specyficznego typu druków o licznych cechach wydawnictw ciągłych (M. Korczyńska-Derkacz, K. Jamrozik). Zainteresowanie tematyką prasoznawczą było i wciąż pozostaje fragmentaryczne, jedynie M. Korczyńska-Derkacz trzykrotnie publikowała prace związane z problematyką prasoznawczą. W czterech tomach, które ukazały się po zmianie tytułu, opublikowano trzy teksty prasoznawcze.

Czasopismo "Studia o Książce” powstało jako wydawnictwo międzyuczelniane w wyniku połączenia trzech, wydawanych w latach $70 . \mathrm{XX}$ w. serii zeszytów naukowych: Uniwersytetu Wrocławskiego („Bibliotekoznawstwo"), Uniwersytetu Adama Mickiewicza w Poznaniu („Biblioteka”) i Uniwersytetu Mikołaja Kopernika w Toruniu („Nauka o Książce”). W myśl założeń redakcyjnych, publikowano przede wszystkim prace księgo- i bibliotekoznawcze, ale dostrzegano zagadnienia pojawiające się na pograniczu nauki o książce, takie jak nauka o informacji, prasoznawstwo i czasopiśmiennictwo, socjologia literatury i życie literackie.

W latach 1970-1993 ukazało się 19 tomów, w których opublikowano 201 artykułów. Wśród 8 prac dotyczących prasoznawstwa można wyróżnić przede wszystkim: trzy artykuły traktujące czasopismo jako źródło do dziejów książki (Artura Pilaka, Elżbiety Słodkowskiej, Danuty Hombek) oraz omawiające konkretne tytuły (Jerzego Franke, Marii Karwackiej). Podejmowana problematyka z interesującego nas zakresu, w całym okresie ukazywania się tytułu, stanowiła zaledwie 3,98\% wszystkich opublikowanych artykułów.

„Roczniki Biblioteczne” powołane do życia w 1957 r. są periodykiem o zasięgu ogólnopolskim, prezentującym szeroki zakres tematyczny: od teorii i historii bibliologii i bibliotekoznawstwa po zagadnienia współczesne dotyczące funkcjonowania bibliotek naukowych i problematykę kształcenia pracowników książki. We Wstępie do pierwszego rocznika redakcja informowała: „Na tematykę Rocznika [...]. złożą się: szeroko pojęta nauka o książce, bibliografia i bibliotekoznawstwo. Obok historii książki i bibliotek znajdzie w nich miejsce historia czasopiśmiennictwa, dzieje papiernictwa i introligatorstwa, zdobnictwo i estetyka książki, zagadnienia bibliofilskie, biografistyka i pamiętnikarstwo związane z książką i jej pracownikami, socjologia książki, zagadnienia czytelnictwa, teoria i naukowa problematyka bibliotekoznawstwa, teoria bibliografii" (Roczniki Biblioteczne, 1957, R. 1, s. 3-4).

W latach 1957-2016 ukazało się 60 roczników, w których opublikowano 846 artykułów. Tematyka prasoznawcza podejmowana była 70 razy, co stanowi $8,27 \%$ wszystkich prac. Większość z nich dotyczyła zagadnień historycznych - dominowały opracowania z zakresu prasy XIX-wiecznej. W latach 60. 
Czasopismo „Studia o Książce” (1970-1993)

\begin{tabular}{|c|c|c|c|c|}
\hline Rok, numer & $\begin{array}{l}\text { Ogólna } \\
\text { liczba art }\end{array}$ & $\begin{array}{l}\text { Liczba art. } \\
\text { prasozn. }\end{array}$ & Autor & Tytuł artykułu \\
\hline $\begin{array}{l}1970, \\
\text { t. } 1-1975, \text { t. } 5\end{array}$ & 55 & 0 & & \\
\hline 1976 , t. 6 & 8 & 1 & Pilak Artur & $\begin{array}{l}\text { Prasowe ogłoszenia księgarskie jako } \\
\text { źródło do dziejów książki }\end{array}$ \\
\hline 1977 , t. 7 & 9 & 0 & & \\
\hline 1978 , t. 8 & 11 & 0 & & \\
\hline 1979 , t. 9 & 10 & 1 & Kosiński Józef Adam & $\begin{array}{l}\text { Biblioteki, książki i czasopisma na- } \\
\text { ukowe w latach 1945-1975 jako kom- } \\
\text { ponenty kulturowego modelu nauki }\end{array}$ \\
\hline 1980, t. 10 & 7 & 0 & & \\
\hline 1981, t. 11 & 8 & 1 & Tadeusiewicz Hanna & $\begin{array}{l}\text { Czasopisma drukarskie galicyjskie } \\
\text { z lat 1872-1900 jako źródło do dzie- } \\
\text { jów drukarstwa polskiego XIX w. }\end{array}$ \\
\hline 1982, t. 12 & 12 & 0 & & \\
\hline \multirow[t]{2}{*}{1983 , t. 13} & \multirow[t]{2}{*}{10} & \multirow[t]{2}{*}{2} & Franke Jerzy & $\begin{array}{l}\text { Program literacki czasopisma } \\
\text { „Bluszcz" w latach 1865-1905 }\end{array}$ \\
\hline & & & Karwacka Maria & $\begin{array}{l}\text { "Libri Gedanenses" - organ Biblioteki } \\
\text { Polskiej Akademii Nauk w Gdańsku }\end{array}$ \\
\hline 1984, t. 14 & 8 & 0 & & \\
\hline \multirow[t]{2}{*}{1985 , t. 15} & \multirow[t]{2}{*}{16} & \multirow[t]{2}{*}{2} & Słodkowska Elżbieta & $\begin{array}{l}\text { Czasopisma pierwszej połowy XIX w. } \\
\text { jako źródło do badań księgoznawczych }\end{array}$ \\
\hline & & & Jazdon Artur & $\begin{array}{l}\text { Walenty Maciej Stefański jako redaktor, } \\
\text { wydawca i drukarz prasy poznańskiej }\end{array}$ \\
\hline 1986 , t. 16 & 12 & 1 & Hombek Danuta & $\begin{array}{l}\text { Ogłoszenia księgarsko-wydawnicze } \\
\text { w czasach stanisławowskich jako źró- } \\
\text { dło bibliologiczne }\end{array}$ \\
\hline $\begin{array}{l}1988, \text { t. } 17- \\
1993, \text { t. } 19\end{array}$ & 35 & 0 & & \\
\hline łącznie & 201 & 8 & & \\
\hline
\end{tabular}

Źródło: obliczenia własne na podstawie analizy zawartości czasopisma „Studia o Książce” (1970-1993).

XX w. publikowali je m.in.: Sławomir Kalembka, Renata Żurkowa i Ewa Kazior, a w latach 70.: Alina Misiowa, Aleksander Zyga i Jadwiga Bogusławska. W kolejnym dziesięcioleciu ukazało się jedynie 10 artykułów o tej tematyce, a po 1990 r. - łącznie 26. W „Rocznikach Bibliotecznych” prace prasoznawcze opublikowało 47 autorów. Autorką 13 tekstów była Hanna Tadeusiewicz. Jej prace ukazywały się w latach 1966-2005, a dotyczyły przede wszystkim czasopism drukarskich, m.in.: „Przeglądu Drukarskiego", "Czcionki” i „Ogniska. Czasopisma dla Spraw Drukarskich i Pokrewnych Zawodów”. Pięć arty- 
Czasopismo „Roczniki Biblioteczne” (1957-2016)

\begin{tabular}{|c|c|c|c|c|}
\hline Rok, tom & $\begin{array}{l}\text { Ogólna } \\
\text { liczba art }\end{array}$ & $\begin{array}{c}\text { Liczba art. } \\
\text { prasozn. }\end{array}$ & Autor & Tytuł artykułu \\
\hline 1 & 2 & 3 & 4 & 5 \\
\hline 1957, R. 1 & 5 & 1 & $\begin{array}{l}\text { Staniszewski } \\
\text { Zdzisław }\end{array}$ & $\begin{array}{l}\text { Pierwsze polskie czasopismo ogłosze- } \\
\text { niowe („Warszawskie Ekstraordyna- } \\
\text { ryjne Tygodniowe Wiadomości”) }\end{array}$ \\
\hline 1958, R. 2 & 6 & 1 & $\begin{array}{l}\text { Staniszewski } \\
\text { Zdzisław }\end{array}$ & $\begin{array}{l}\text { Tematyka literacka na łamach „War- } \\
\text { szawskich Ekstraordynaryjnych Ty- } \\
\text { godniowych Wiadomości” }\end{array}$ \\
\hline 1959, R. 3 & 8 & 1 & Skura Adam & $\begin{array}{l}\text { Tygodnik Polski poświęcony włościa- } \\
\text { nom. Pszczyna 1845-1846 }\end{array}$ \\
\hline $\begin{array}{l}\text { 1960, } \\
\text { R. 4-1962, } \\
\text { R. 6, z. 3-4 }\end{array}$ & 39 & 0 & & \\
\hline $\begin{array}{l}\text { 1963, R. 7, } \\
\text { z. 1-2, }\end{array}$ & 7 & 1 & Kalembka Sławomir & $\begin{array}{l}\text { Prasa Towarzystwa Demokratyczne- } \\
\text { go Polskiego. Zarys dziejów wydaw- } \\
\text { niczych 1832-1863 }\end{array}$ \\
\hline $\begin{array}{l}\text { 1964, R. } 8, \\
\text { z. } 1-2\end{array}$ & 18 & 0 & & \\
\hline $\begin{array}{l}\text { 1965, R. 9, } \\
\text { z. } 1-2\end{array}$ & 8 & 1 & Żurkowa Renata & $\begin{array}{l}\text { "Rozmaitości Naukowe" - krakow- } \\
\text { skie pismo naukowe (1828-1831) }\end{array}$ \\
\hline \multirow[t]{2}{*}{$\begin{array}{l}\text { 1966, R. 10, } \\
\text { z. 1-2 }\end{array}$} & 13 & 2 & Tadeusiewicz Hanna & $\begin{array}{l}\text { Zapomniane czasopismo warszawskie } \\
\text { z epoki przedlistopadowej („Chwila } \\
\text { Spoczynku” 1827) }\end{array}$ \\
\hline & & & Jaworska Janina & $\begin{array}{l}\text { "Goniec Łódzki" (1898-1906) wobec } \\
\text { rosyjskiej cenzury }\end{array}$ \\
\hline \multirow[t]{3}{*}{ 1967, R. 11} & 20 & 3 & Kazior Ewa & $\begin{array}{l}\text { „Dziennik Literacki” w latach } 1852- \\
1854 \text { i jego wpływ na życie umysło- } \\
\text { we Galicji }\end{array}$ \\
\hline & & & Jaworska Janina & $\begin{array}{l}\text { Niemiecka cenzura prasowa w Łodzi } \\
\text { w okresie I wojny światowej }\end{array}$ \\
\hline & & & Albin Janusz & $\begin{array}{l}\text { "Śląsk" 1946-1948. Zarys monograficz- } \\
\text { ny i bibliografia zawartości }\end{array}$ \\
\hline $\begin{array}{l}\text { 1968, R. 12, } \\
\text { z. } 1-4\end{array}$ & 14 & 1 & Świderski Bolesław & $\begin{array}{l}\text { Problematyka gromadzenia bieżących } \\
\text { czasopism zagranicznych w bibliote- } \\
\text { kach polskich }\end{array}$ \\
\hline $\begin{array}{l}\text { 1969, R. 13, } \\
\text { z. 1-2 }\end{array}$ & 20 & 1 & Albin Janusz & $\begin{array}{l}\text { Przyczynek do dziejów polskiej prasy } \\
\text { obozowej w latach okupacji }\end{array}$ \\
\hline \multirow[t]{3}{*}{ 1970, R. 14} & 31 & 3 & Gramatowski Wiktor & $\begin{array}{l}\text { Franciszek Bohomolec - wydawca, } \\
\text { prefekt drukarni i redaktor "Wiado- } \\
\text { mości Warszawskich" }\end{array}$ \\
\hline & & & Ratajewski Jerzy & $\begin{array}{l}\text { Informacja o książce, bibliotekach } \\
\text { i czytelnictwie na łamach czasopism } \\
\text { polskich w Opolu w latach 1911-1921 }\end{array}$ \\
\hline & & & $\begin{array}{l}\text { Chwastek } \\
\text { Aleksandra }\end{array}$ & $\begin{array}{l}\text { Z badań nad czytelnictwem prasy } \\
\text { wśród więźniów }\end{array}$ \\
\hline
\end{tabular}




\begin{tabular}{|c|c|c|c|c|}
\hline 1 & 2 & 3 & 4 & 5 \\
\hline \multirow[t]{3}{*}{$\begin{array}{l}\text { 1971, R. 15, } \\
\text { z. 1-2 }\end{array}$} & 12 & 3 & Borkowska Helena & $\begin{array}{l}\text { "Magazyn Warszawski Pięknych } \\
\text { Nauk" Piotra Świtkowskiego }\end{array}$ \\
\hline & & & Kubicka Weronika & Czasopisma bibliologiczne litewskie \\
\hline & & & Tadeusiewicz Hanna & $\begin{array}{l}\text { "Przegląd Drukarski" - nieznane cza- } \\
\text { sopismo fachowe z końca XIX w. }\end{array}$ \\
\hline $\begin{array}{l}\text { 1971, R. 15, } \\
\text { z. 3-4 }\end{array}$ & 7 & 0 & & \\
\hline \multirow[t]{4}{*}{$\begin{array}{l}\text { 1972, R. 16, } \\
\text { z. 1-2 }\end{array}$} & 19 & 4 & Misiowa Alina & $\begin{array}{l}\text { Sprawy słowiańskie w czasopismach } \\
\text { krakowskich w latach 1834-1838. }\end{array}$ \\
\hline & & & Dorembowicz Michał & $\begin{array}{l}\text { Naukowe czasopisma zagraniczne } \\
\text { w Polsce }\end{array}$ \\
\hline & & & Łapacz Teresa & $\begin{array}{l}\text { Zasoby czasopiśmiennicze w biblio- } \\
\text { tekach warszawskich po wyzwole- } \\
\text { niu i w } 1968 \text { r. oraz postulaty ich } \\
\text { uzupełnienia }\end{array}$ \\
\hline & & & Radożycki Jan & $\begin{array}{l}\text { Dziesięciolecie czasopisma "Polish } \\
\text { Scientific Periodicals-Contents” (Ana- } \\
\text { liza krytyczna na tle tendencji świa- } \\
\text { towych). }\end{array}$ \\
\hline \multirow[t]{3}{*}{$\begin{array}{l}\text { 1973, R. 17, } \\
\text { z. 1-2 }\end{array}$} & 27 & 3 & $\begin{array}{l}\text { Przywecka-Samecka } \\
\text { Maria }\end{array}$ & $\begin{array}{l}\text { Rozwój czasopiśmiennictwa muzycz- } \\
\text { nego (Zarys historyczny) }\end{array}$ \\
\hline & & & $\begin{array}{l}\text { Cieślak Tadeusz, } \\
\text { Wasilewska Danuta }\end{array}$ & $\begin{array}{l}\text { Czytelnictwo czasopism zawodowych } \\
\text { wśród studentów wyższych szkół rol- } \\
\text { niczych w aspekcie warunków środo- } \\
\text { wiskowych }\end{array}$ \\
\hline & & & Żyga Aleksander & $\begin{array}{l}\text { Krakowski „Świat” (1888-1895). Z. Sar- } \\
\text { neckiego. Mało znana karta z dziejów } \\
\text { ilustracji polskiej XIX w. }\end{array}$ \\
\hline \multirow[t]{2}{*}{ 1974, R. 18} & 28 & 2 & Tadeusiewicz Hanna & $\begin{array}{l}\text { "Przegląd Drukarski" Seweryna } \\
\text { Baylego }\end{array}$ \\
\hline & & & $\begin{array}{l}\text { Cieślak Tadeusz, } \\
\text { Wasilewska Danuta }\end{array}$ & $\begin{array}{l}\text { Postępy w nauce w świetle czytelnic- } \\
\text { twa czasopism zawodowych wśród } \\
\text { studentów. Analiza w aspekcie róż- } \\
\text { nic środowiskowych }\end{array}$ \\
\hline $\begin{array}{l}\text { 1975, R. 19, } \\
\text { z. 1-2 }\end{array}$ & 18 & 1 & Tadeusiewicz Hanna & $\begin{array}{l}\text { „Budzik” (1883) - pismo drukarzy kra- } \\
\text { kowskich }\end{array}$ \\
\hline \multirow[t]{2}{*}{$\begin{array}{l}\text { 1976, R. 20, } \\
\text { z. } 1-2\end{array}$} & 25 & 2 & Tadeusiewicz Hanna & $\begin{array}{l}\text { "Przewodnik dla Spraw Drukarsko- } \\
\text {-Litograficznych" - lwowskie czaso- } \\
\text { pismo fachowe z końca XIX w. }\end{array}$ \\
\hline & & & Tadeusiewicz Hanna & $\begin{array}{l}\text { "Praca. Dwutygodnik poświęcony } \\
\text { sprawom drukarskim" (Lwów 1878) }\end{array}$ \\
\hline \multirow[t]{2}{*}{$\begin{array}{l}\text { 1977, R. 21, } \\
\text { z. 1-2, }\end{array}$} & 27 & 2 & Bogusławska Jadwiga & $\begin{array}{l}\text { "Tydzień" piotrkowski (1873-1906) } \\
\text { jako źródło do dziejów książki polskiej }\end{array}$ \\
\hline & & & Tadeusiewicz Hanna & $\begin{array}{l}\text { "Czcionka" (1872-1876) - pierwsze } \\
\text { czasopismo drukarskie w Polsce }\end{array}$ \\
\hline $\begin{array}{l}\text { 1978, R. 22, } \\
\text { z. } 1-2\end{array}$ & 15 & 1 & Tadeusiewicz Hanna & $\begin{array}{l}\text { "Ognisko. Czasopismo dla Spraw } \\
\text { Drukarskich i Pokrewnych Zawo- } \\
\text { dów" (okres pierwszy: 1895-1900) }\end{array}$ \\
\hline
\end{tabular}




\begin{tabular}{|c|c|c|c|c|}
\hline 1 & 2 & 3 & 4 & 5 \\
\hline $\begin{array}{l}\text { 1978, R. 22, } \\
\text { z. 3-4-1979, } \\
\text { R. 23, z. 1-2 }\end{array}$ & 16 & 0 & & \\
\hline $\begin{array}{l}\text { 1979, R. 23, } \\
\text { z. 3-4 }\end{array}$ & 8 & 1 & Tadeusiewicz Hanna & „Grafika” (1912) \\
\hline $\begin{array}{l}\text { 1980, R. 24, } \\
\text { z. } 1\end{array}$ & 9 & 0 & & \\
\hline $\begin{array}{l}\text { 1980, R. } 24, \\
\text { z. } 2\end{array}$ & 12 & 1 & $\begin{array}{l}\text { Bednarska-Ruszajo- } \\
\text { wa Krystyna }\end{array}$ & $\begin{array}{l}\text { Zagadnienia wytwarzania i rozpo- } \\
\text { wszechniania książki na łamach „Mo- } \\
\text { nitora” (1765-1785) }\end{array}$ \\
\hline $\begin{array}{l}\text { 1981, R. 25, } \\
\text { z. } 1-2\end{array}$ & 8 & 0 & & \\
\hline $\begin{array}{l}\text { 1982, R. 26, } \\
\text { z. } 1-2\end{array}$ & 15 & 1 & Tadeusiewicz Hanna & $\begin{array}{l}\text { Organizacje zawodowe drukarzy } \\
\text { lwowskich w świetle ich prasy facho- } \\
\text { wej z lat 1872-1900 }\end{array}$ \\
\hline $\begin{array}{l}\text { 1983, R. 27, } \\
\text { z. 1-2- 1985, } \\
\text { R. } 29, \text { z. } 1-2\end{array}$ & 67 & 0 & & \\
\hline \multirow[t]{2}{*}{$\begin{array}{l}\text { 1986, R. 30, } \\
\text { z. } 1-2\end{array}$} & 20 & 2 & Tadeusiewicz Hanna & $\begin{array}{l}\text { „Pracownik Graficzny” (1928-1939). } \\
\text { Część I. Powstanie czasopisma. Za- } \\
\text { gadnienia fachowe. }\end{array}$ \\
\hline & & & Czachowski Marek & Czasopisma bibliofilskie \\
\hline \multirow[t]{3}{*}{ 1987, R. 31} & 25 & 3 & Hombek Danuta & $\begin{array}{l}\text { Reklama książki na łamach „Gazety } \\
\text { Warszawskiej” w latach 1764-1795 }\end{array}$ \\
\hline & & & Tadeusiewicz Hanna & $\begin{array}{l}\text { "Pracownik Graficzny” (1928-1939). } \\
\text { Część II. Problematyka i zawodowa }\end{array}$ \\
\hline & & & $\begin{array}{l}\text { Korczyńska-Derkacz } \\
\text { Małgorzata }\end{array}$ & $\begin{array}{l}\text { Problematyka badań nad czasopiś- } \\
\text { miennictwem naukowym }\end{array}$ \\
\hline $\begin{array}{l}\text { 1988, R. 32, } \\
\text { z. } 1\end{array}$ & 14 & 0 & & \\
\hline $\begin{array}{l}\text { 1988, R. 32, } \\
\text { z. } 2\end{array}$ & 12 & 1 & Czernianin Halina & $\begin{array}{l}\text { Dzieje wydawnicze „Tygodnika Wi- } \\
\text { leńskiego" }\end{array}$ \\
\hline \multirow[t]{2}{*}{$\begin{array}{l}\text { 1989, R. 33, } \\
\text { z. 1-2 }\end{array}$} & 12 & 2 & $\begin{array}{l}\text { Czerwińska } \\
\text { Małgorzata }\end{array}$ & $\begin{array}{l}\text { Polskie czasopisma dla niewidomych } \\
\text { w latach 1945-1988 }\end{array}$ \\
\hline & & & Gzella Grażyna & $\begin{array}{l}\text { Czytelnictwo gazet przez Polaków } \\
\text { w obozach koncentracyjnych }\end{array}$ \\
\hline \multirow[t]{2}{*}{$\begin{array}{l}\text { 1990, R. 34, } \\
\text { z. 1-2 }\end{array}$} & 8 & 2 & Kowalska Hanna & $\begin{array}{l}\text { Polskie czasopisma nutowe I dodatki } \\
\text { nutowe do czasopism w okresie za- } \\
\text { borów }\end{array}$ \\
\hline & & & $\begin{array}{l}\text { Korczyńska-Derkacz } \\
\text { Małgorzata }\end{array}$ & $\begin{array}{l}\text { Informacja o nauce w „Roczniku To- } \\
\text { warzystwa Przyjaciół Nauk Poznań- } \\
\text { skiego" (1860-1928) }\end{array}$ \\
\hline \multirow[t]{2}{*}{$\begin{array}{l}\text { 1991, R. 35, } \\
\text { z. 1-2, }\end{array}$} & 19 & 2 & Pilak Artur & $\begin{array}{l}\text { Ksiegarstwo Ślaskie w latach 1785- } \\
1875 \text { w świetle "Schlesische Provin- } \\
\text { zialblatter" }\end{array}$ \\
\hline & & & Herden Elżbieta & $\begin{array}{l}\text { Działalność płatnych wypożyczal- } \\
\text { ni w świetle "Schlesische Provinzial- } \\
\text { blätter" w latach 1785-1875 }\end{array}$ \\
\hline
\end{tabular}




\begin{tabular}{|c|c|c|c|c|}
\hline 1 & 2 & 3 & 4 & 5 \\
\hline \multirow[t]{2}{*}{$\begin{array}{l}1992, \text { R. } 36 \\
\text { z. } 1-2\end{array}$} & 12 & 2 & $\begin{array}{l}\text { Korczyńska-Derkacz } \\
\text { Małgorzata }\end{array}$ & $\begin{array}{l}\text { Czasopiśmiennictwo naukowe XIX w. } \\
\text { Definicje i typologia }\end{array}$ \\
\hline & & & Gzella Grażyna & $\begin{array}{l}\text { Udział duchowieństwa w tworzeniu } \\
\text { „pism dla ludu” w I połowie XIX w. }\end{array}$ \\
\hline $\begin{array}{l}\text { 1993, R. 37, } \\
\text { z. } 1-2\end{array}$ & 10 & 1 & Gzella Grażyna & $\begin{array}{l}\text { "Pismo dla ludu" - postulaty i działa- } \\
\text { nia w sprawie realizacji tego hasła do } \\
\text { połowy XIX w. }\end{array}$ \\
\hline $\begin{array}{l}\text { 1994, R. 38, } \\
\text { z. 1-2 }\end{array}$ & 12 & 1 & Kalczyńska Maria & $\begin{array}{l}\text { Wydawnictwo prasowe "Nowiny" } \\
\text { w Opolu 1911-1939 }\end{array}$ \\
\hline $\begin{array}{l}\text { 1995, R. 39, } \\
\text { z. 1-2 }\end{array}$ & 7 & 0 & & \\
\hline \multirow[t]{2}{*}{$\begin{array}{l}\text { 1996, R. 40, } \\
\text { z. 1-2 }\end{array}$} & 7 & 2 & Gzella Grażyna & $\begin{array}{l}\text { Czasopisma dla chłopów w dobie po- } \\
\text { wstania styczniowego }\end{array}$ \\
\hline & & & Pietrykiewicz Iwona & $\begin{array}{l}\text { Publikacje Bronisława Ferdynanda } \\
\text { Trentowskiego i ich krytyka na ła- } \\
\text { mach czasopism wielkopolskich w la- } \\
\text { tach } 1840-1845\end{array}$ \\
\hline $\begin{array}{l}\text { 1997, R. 41, } \\
\text { z. 1-2 }\end{array}$ & 9 & 0 & & \\
\hline 1998, R. 42 & 3 & 1 & Piskorz Jolanta & $\begin{array}{l}\text { Ośrodek wydawniczy czasopism sal- } \\
\text { watoriańskich w Trzebini (1906-1946) }\end{array}$ \\
\hline 1999, R. 43 & 5 & 1 & Czernianin Halina & $\begin{array}{l}\text { Ogłoszenia wydawnicze i księgarskie } \\
\text { w „Tygodniku Wileńskim” 1815-1822 }\end{array}$ \\
\hline $\begin{array}{l}2000, \text { R. } 44- \\
2001, \text { R. } 45\end{array}$ & 18 & 0 & & \\
\hline \multirow[t]{3}{*}{ 2002, R. 46} & 18 & 3 & $\begin{array}{l}\text { Żbikowska-Migoń } \\
\text { Anna }\end{array}$ & $\begin{array}{l}\text { U początków bibliografii czasopism: } \\
\text { Christiana Junckera Schediasma histo- } \\
\text { ricum de ephemeridibus sive diariis } \\
\text { eruditorum (1692) }\end{array}$ \\
\hline & & & $\begin{array}{l}\text { Czarnik Oskar } \\
\text { Stanisław }\end{array}$ & $\begin{array}{l}\text { Gazety ulotne związane ze Lwowem } \\
\text { w XVII i na początku XVIII wieku }\end{array}$ \\
\hline & & & Szczepaniec Józef & $\begin{array}{l}\text { Wokół „Courrier de Polone” (1776- } \\
\text { 1777) Jana Augusta Posera }\end{array}$ \\
\hline $\begin{array}{l}\text { 2003, R. } 47- \\
2004, \text { R. } 48\end{array}$ & 12 & 0 & & \\
\hline \multirow[t]{6}{*}{ 2005, R. 49} & 38 & 6 & Biały Franciszek & Z dziejów prasy kłodzkiej (do 1945 r.) \\
\hline & & & Jazdon Artur & $\begin{array}{l}\text { Poznańskie XIX-wieczne czasopisma } \\
\text { satyryczne }\end{array}$ \\
\hline & & & Walczak Krzysztof & $\begin{array}{l}\text { "Dziennik Kaliski". Zapomniana inicja- } \\
\text { tywa wydawnicza drukarzy kaliskich }\end{array}$ \\
\hline & & & Tadeusiewicz Hanna & $\begin{array}{l}\text { "Poradnik Graficzny” (1905-1906) } \\
\text { i „Polski Poradnik Graficzny” (1908). } \\
\text { Przyczynek do dziejów czasopiśmien- } \\
\text { nictwa fachowego drukarzy }\end{array}$ \\
\hline & & & $\begin{array}{l}\text { Korczyńska-Derkacz } \\
\text { Małgorzata }\end{array}$ & $\begin{array}{l}\text { "Życie" krakowskie (1897-1900) źró- } \\
\text { dłem informacji o kulturze czeskiej }\end{array}$ \\
\hline & & & Aleksiewicz Anna & $\begin{array}{l}\text { Spór Karola Cieszewskiego, redakto- } \\
\text { ra pisma „Czytelnia dla Młodzieży”, } \\
\text { z Dyrekcją Policji we Lwowie-w świe- } \\
\text { tle zachowanej korespondencji }\end{array}$ \\
\hline
\end{tabular}




\begin{tabular}{|c|c|c|c|c|}
\hline 1 & 2 & 3 & 4 & 5 \\
\hline \multirow[t]{2}{*}{ 2006, R. 50} & 6 & 2 & Boczar Elżbieta & $\begin{array}{l}\text { Krytyka literatury dziecięcej i mło- } \\
\text { dzieżowej w polskich czasopismach } \\
\text { i katalogach księgarskich w XIX w. }\end{array}$ \\
\hline & & & Wandel Agnieszka & $\begin{array}{l}\text { „Bulletin des bibliothèques de Fran- } \\
\text { ce" czasopismo o bibliotekach nie tyl- } \\
\text { ko francuskich }\end{array}$ \\
\hline 2007, R. 51 & 8 & 1 & Wodniak Katarzyna & $\begin{array}{l}\text { Udział tygodnika "Przyjaciółka” } \\
\text { w upowszechnianiu czytelnictwa ma- } \\
\text { sowego w powojennym 40-leciu }\end{array}$ \\
\hline $\begin{array}{l}2008, \text { R. } 52- \\
2015, \text { R. } 59\end{array}$ & 54 & 0 & & \\
\hline \multirow[t]{2}{*}{ 2016, R. 60} & 15 & 2 & $\begin{array}{l}\text { Korczyńska-Derkacz } \\
\text { Małgorzata, } \\
\text { Łuszpak Agnieszka }\end{array}$ & $\begin{array}{l}\text { „Studia o Książce” (1970-1993) - kon- } \\
\text { cepcje programowe i ich realizacja }\end{array}$ \\
\hline & & & Jamrozik Katarzyna & $\begin{array}{l}\text { Problematyka badan nad jednodniów- } \\
\text { kami w Polsce }\end{array}$ \\
\hline łącznie & 846 & 70 & & \\
\hline
\end{tabular}

Źródło: obliczenia własne na podstawie analizy zawartości czasopisma „Roczniki Biblioteczne” (1957-2016).

kułów opublikowała M. Korczyńska-Derkacz (jedno współautorstwo), cztery - Grażyna Gzella i po dwie prace przedstawili Janina Jaworska, Halina Czernianin, Janusz Albin, Zdzisław Staniszewski oraz wspólnie Danuta Wasilewska i Tadeusz Cieślak. Wśród podejmowanych tematów znalazły się dzieje wydawnicze konkretnych tytułów, czasopisma fachowe, dla ludu, naukowe i literackie, gazety i czasopisma z punktu widzenia ich wartości jako źródła informacji o ruchu wydawniczym, prasa w konkretnym okresie historycznym lub na danym terenie, cenzura prasowa. Autorzy kilku publikacji omawiali zagadnienia współczesne dotyczące gromadzenia czasopism, ich czytelnictwa. W latach 2008-2015 w "Rocznikach Bibliotecznych” nie ukazał się żaden artykuł o tematyce prasoznawczej - zagadnienia te powróciły w $2016 \mathrm{r}$.

Instytut Informacji Naukowej i Studiów Bibliologicznych Uniwersytetu Warszawskiego (obecnie katedry na Wydziale Dziennikarstwa, Informacji i Bibliologii Uniwersytetu Warszawskiego) w 1975 r. rozpoczął wydawanie czasopisma „Z Badań nad Polskimi Księgozbiorami Historycznymi”. Nieregularnie ukazujący się rocznik w 2006 r. zmienił tytuł na "Z Badań nad Książką i Księgozbiorami Historycznymi". W założeniu redaktorów: "Czasopismo publikuje rezultaty badań z zakresu szeroko pojętej kultury książki w kontekście historycznym. Jego zadaniem jest oferowanie wszechstronnego forum dla ogłaszania dorobku i wymiany myśli środowiska bibliologów polskich oraz poprzez zapraszanie do współpracy badaczy zagranicznych prezentowanie najnowszych dokonań, inicjatyw i trendów 
Czasopismo „Z Badań nad Polskimi Księgozbiorami Historycznymi” oraz jego kontynuacja „Z Badań nad Książką i Księgozbiorami Historycznymi” (1975-2016)

\begin{tabular}{|c|c|c|c|c|}
\hline $\begin{array}{l}\text { Rok, zeszyt } \\
\quad \text { (tom) }\end{array}$ & $\begin{array}{l}\text { Ogólna } \\
\text { liczba art. }\end{array}$ & $\begin{array}{l}\text { Liczba art. } \\
\text { prasozn. }\end{array}$ & Autor & Tytuł artykułu \\
\hline $\begin{array}{l}\text { 1975, } \\
\text { z. } 1-1980, \\
\text { z. } 4\end{array}$ & 25 & 0 & & \\
\hline \multirow[t]{2}{*}{ 1981, z. 5} & 9 & 2 & Socha Irena & $\begin{array}{l}\text { Wartość źródłowa czasopism młodzie- } \\
\text { ży szkolnej }\end{array}$ \\
\hline & & & Grzelecki Wojciech & $\begin{array}{l}\text { Zarys problematyki książki, biblio- } \\
\text { tek i czytelnictwa w "Monitorze" } \\
(1765-1785)\end{array}$ \\
\hline $\begin{array}{l}\text { 1981, } \\
\text { z. } 6-1993, \\
\text { z. } 15\end{array}$ & 67 & 0 & & \\
\hline \multirow[t]{3}{*}{$\begin{array}{l}\text { 1993, } \\
\text { z. specjalny }\end{array}$} & 37 & 3 & Tadeusiewicz Hanna & $\begin{array}{l}\text { „Biesiada Literacka” za czasów redak- } \\
\text { torstwa Gracjana Ungra (1876-1881) }\end{array}$ \\
\hline & & & Ihnatowicz Ireneusz & Lista prenumeratorów „Izys Polskiej” \\
\hline & & & $\begin{array}{l}\text { Stasiewicz-Jasiuko- } \\
\text { wa Irena }\end{array}$ & $\begin{array}{l}\text { Czy Krzysztof Hilary Szembek jest } \\
\text { „współojcem” "Zbioru potrzebniej- } \\
\text { szych wiadomości”? }\end{array}$ \\
\hline $\begin{array}{l}1995, \text { z. } 16- \\
2003, \text { t. } 21\end{array}$ & 67 & 0 & & \\
\hline $\begin{array}{l}2004, \text { t. spe- } \\
\text { cjalny }\end{array}$ & 16 & 0 & & \\
\hline \multicolumn{5}{|c|}{ Z Badań nad Książką i Księgozbiorami Historycznymi (nowa numeracja tomów) } \\
\hline $\begin{array}{l}2006, \text { t. } 1- \\
2015, \text { t. } 9\end{array}$ & 65 & 0 & & \\
\hline 2016 , t. 10 & 19 & 1 & Łuszpak Agnieszka & $\begin{array}{l}\text { Obraz katalogów rzeczowych na ła- } \\
\text { mach polskich czasopism bibliotekar- } \\
\text { skich w okresie stalinowskim }\end{array}$ \\
\hline łącznie & 305 & 6 & & \\
\hline
\end{tabular}

Źródło: obliczenia własne na podstawie analizy zawartości czasopism: „Z Badań nad Polskimi Księgozbiorami Historycznymi” oraz jego kontynuacji "Z Badań nad Książką i Księgozbiorami Historycznymi" (1975-2016).

w badaniach nad kulturą książki na świecie" (Z Badań nad Książka i Księgozbiorami Historycznymi [online], [dostęp: 25.04.2017]. Dostępny w WWW: http://www.lis.uw.edu.pl/badan/?page_id=82).

W świetle założeń programowych nie dziwi brak zainteresowania tematyką prasoznawczą - na 289 artykułów, które znalazły się w 33 tomach obydwu tytułów, zaledwie 6 poruszało te zagadnienia.

Prace prasoznawcze pojawiają się tu sporadycznie i stanowią jedynie 2,07\% wszystkich opublikowanych artykułów. 
W 1982 r. pod redakcją Jerzego Jarowieckiego ukazał się pierwszy tom „Prac Bibliotekoznawczych” w serii „Roczników Naukowo-Dydaktycznych Wyższej Szkoły Pedagogicznej w Krakowie”. Jak czytamy we wstępie: „Zawarto w nim publikacje pracowników Samodzielnego Zakładu Bibliotekoznawstwa WSP w Krakowie. (...) Zamieszczone w tym tomie publikacje są rezultatem poczynań badawczych podjętych w czterech zespołach i pracowniach naukowo-dydaktycznych, powołanych w kwietniu 1979 r. Są to: Zespół Książki i Czytelnictwa, Zespół Czasopiśmiennictwa Polskiego i Zagadnień Wydawniczych, Zespół Historii i Funkcji Bibliotek oraz Zespół Bibliografii i Informacji Naukowej" (Jarowiecki, 1982).

Do 1998 r. ukazało się 9 tomów z 82 artykułami, z których 34,15\% można zakwalifikować do prasoznawstwa. Na tom przypadały średnio trzy prace $\mathrm{z}$ tego zakresu - w każdym numerze publikowana była co najmniej jedna. 28 artykułów zostało napisanych przez 15 osób, z których najwięcej - po cztery - przedstawili Jan Bujak i Władysława Wójcik. Poruszana tematyka dotyczyła czasopisma jako źródła informacji o książce i jej instytucjach, przedstawiano konkretne tytuły w ujęciu historycznym, sporo miejsca poświęcono czasopismom Krakowa i Lwowa, prasie w okresie międzywojennym i w okresie okupacji. Kontynuacją „Prac Bibliotekoznawczych” jest „Annales Universitatis Paedagogicae Cracoviensis. Studia ad Bibliothecarum Scientiam Pertinentia", ukazujące się jako rocznik, na łamach którego publikowane są oryginalne wyniki badań z zakresu szeroko pojętej bibliologii i informatologii. W latach 2001-2016 ukazało się 14 numerów, w których tematyka prasoznawcza wciąż się pojawiała - na 155 artykułów 38, czyli 24,52\% dotyczyło tej problematyki. Po tomach z lat 2012 i 2013, kiedy zagadnienia te nie były w ogóle obecne, w 2015 r. wydano tom 13, w którym na 14 artykułów aż 12 odnosiło się do czasopism przeznaczonych dla dzieci i młodzieży. Powracały tematy związane z czasopismami regionu, stanowiąc w całym omawianym okresie blisko $50 \%$ prac.

Instytut Bibliotekoznawstwa i Informacji Naukowo-Technicznej Uniwersytetu Jana Kochanowskiego w Kielcach (obecnie Instytut Dziennikarstwa i Informacji) w 1993 r. rozpoczął nieregularne wydawanie czasopisma „Kieleckie Studia Bibliologiczne".

W sześciu pierwszych tomach artykuły prasoznawcze stanowiły blisko $1 / 3(31,15 \%)$ wszystkich opublikowanych. Po zmianie tytułu na „Studia Bibliologiczne Akademii Świętokrzyskiej”, w latach 2003-2008, zamieszczono łącznie 46 prac, które zdominowała tematyka związana z czasopiśmiennictwem - było to aż 67,39\% - zdecydowanie najwięcej ze wszystkich badanych periodyków. Autorzy poruszali zagadnienia prasy regionalnej Kielecczyzny, prasy wyodrębnionych okresów historycznych (okres międzywojnia i II wojny światowej, czasy stalinizmu, przełomu 1989 r.), omawiano poszczególne tytuły prasowe. W 2009 r. nastąpiła kolejna zmiana tytułu na 
Tabela 5

Czasopismo „Rocznik Naukowo-Dydaktyczny. Prace Bibliotekoznawcze” oraz jego kontynuacja "Annales Universitatis Paedagogicae Cracoviensis Studia ad Bibliothecarum Scientiam Pertinentia"

(1982-2016)

\begin{tabular}{|c|c|c|c|c|}
\hline Rok, tom & $\begin{array}{l}\text { Ogólna } \\
\text { liczba art }\end{array}$ & $\begin{array}{l}\text { liczba art. } \\
\text { prasozn. }\end{array}$ & Autor & Tytuł artykułu \\
\hline 1 & 2 & 3 & 4 & 5 \\
\hline \multirow[t]{2}{*}{1982, t. 1} & 11 & 2 & Bujak Jan & $\begin{array}{l}\text { Informacja o książce i prasie w XIX- } \\
\text {-wiecznych tygodnikach galicyjskich } \\
\text { dla ludu }\end{array}$ \\
\hline & & & Sokół Zofia & $\begin{array}{l}\text { "Przodownice" (1899-1912). Zarys } \\
\text { monograficzny }\end{array}$ \\
\hline 1984 , t. 2 & 5 & 1 & Wójcik Władysława & $\begin{array}{l}\text { Problem tzw. produkcji dóbr niemate- } \\
\text { rialnych na łamach niemieckiej prasy } \\
\text { w języku polskim wydawanej w Ge- } \\
\text { neralnej Guberni w latach 1939-1945 }\end{array}$ \\
\hline \multirow[t]{3}{*}{1985 , t. 3} & 6 & 3 & Krotos Wanda & $\begin{array}{l}\text { Wiersze patriotyczne w prasie kra- } \\
\text { kowskiej w latach } 1795-1830\end{array}$ \\
\hline & & & Sokół Zofia & $\begin{array}{l}\text { Konspiracyjne czasopisma Wojskowej } \\
\text { Służby Kobiet i organizacji z nią zwią- } \\
\text { zanych 1939-1944 }\end{array}$ \\
\hline & & & Wójcik Władysława & $\begin{array}{l}\text { Stan i potrzeby badań niemieckiej pra- } \\
\text { sy w języku polskim dla Polaków z lat } \\
1939-1945 \text { wydawanej w Generalnym } \\
\text { Gubernatorstwie }\end{array}$ \\
\hline 1987 , t. 4 & 8 & 1 & Wójcik Władysława & $\begin{array}{l}\text { Niemiecka prasa w języku polskim dla } \\
\text { Polaków wydawana w Generalnym } \\
\text { Gubernatorstwie w latach 1939-1945. } \\
\text { Ogólna charakterystyka }\end{array}$ \\
\hline \multirow[t]{6}{*}{1990 , t. 5} & 9 & 6 & Bujak Jan & $\begin{array}{l}\text { Redakcja i administracja „Tygodnia” } \\
\text { (1.X.1874-31.XII.1881) }\end{array}$ \\
\hline & & & Socha Irena & $\begin{array}{l}\text { Stan i potrzeby badań nad czasopiś- } \\
\text { miennictwem dziecięcym i młodzie- } \\
\text { żowym do 1939. Część I: Badania nad } \\
\text { periodykami do roku } 1918\end{array}$ \\
\hline & & & Toczek Alfred & $\begin{array}{l}\text { Redakcja i współpracownicy tygodni- } \\
\text { ka „Piast” w latach 1918-1926 }\end{array}$ \\
\hline & & & Pietrzyk Bożena & $\begin{array}{l}\text { Problemy kultury i literatury w prasie } \\
\text { konspiracyjnej ruchu ludowego }\end{array}$ \\
\hline & & & Wójcik Władysława & $\begin{array}{l}\text { Język prasy gadzinowej lat 1939-1945 } \\
\text { na tle metod niemieckiej propagandy }\end{array}$ \\
\hline & & & Góra Barbara & $\begin{array}{l}\text { „Pomagamy sobie w pracy” (1956- } \\
1983 \text { ) }\end{array}$ \\
\hline \multirow[t]{2}{*}{1991 , t. 6} & 8 & 4 & Konopka Maria & $\begin{array}{l}\text { "Przyjaciel Domowy" Hipolita Stup- } \\
\text { nickiego (1851-1878) }\end{array}$ \\
\hline & & & Toczek Alfred & $\begin{array}{l}\text { Prasa Polskiej Patrii Socjalistycznej } \\
\text { i Niezależnych Socjalistów w Krako- } \\
\text { wie w latach 1918-1939 }\end{array}$ \\
\hline
\end{tabular}




\begin{tabular}{|c|c|c|c|c|}
\hline 1 & 2 & 3 & 4 & 5 \\
\hline & & & Socha Irena & $\begin{array}{l}\text { Stan i potrzeby badań nad czasopiś- } \\
\text { miennictwem dziecięcym i młodzieżo- } \\
\text { wym do } 1939 \text {. Część II: Badania nad } \\
\text { periodykami okresu międzywojennego }\end{array}$ \\
\hline & & & Jarowiecki Jerzy & $\begin{array}{l}\text { Początki prasy krakowskiej po } 1945 \\
\text { roku }\end{array}$ \\
\hline \multirow[t]{4}{*}{1993, t. 7} & 12 & 4 & Bujak Jan & $\begin{array}{l}\text { "Ruch" i „Tydzień" - dwa lwowskie } \\
\text { periodyki lat 70. XIX w. }\end{array}$ \\
\hline & & & $\begin{array}{l}\text { Faber-Chojnacka } \\
\text { Lidia }\end{array}$ & $\begin{array}{l}\text { Czasopisma dziecięce i młodzieżowe } \\
\text { w Krakowie w dwudziestoleciu mię- } \\
\text { dzywojennym i ich charakterystyka } \\
\text { ilościowa }\end{array}$ \\
\hline & & & Glogier Marek & $\begin{array}{l}\text { Międzywojenne periodyki kościelne } \\
\text { metropolii lwowskiej. Przegląd typo- } \\
\text { logiczno-statystyczny }\end{array}$ \\
\hline & & & Jarowiecki Jerzy & $\begin{array}{l}\text { Prasa podziemna na Śląsku i w Zagłę- } \\
\text { biu Dąbrowskim w latach 1939-1945 }\end{array}$ \\
\hline \multirow[t]{6}{*}{1996 , t. 8} & 12 & 6 & Jarowiecki Jerzy & $\begin{array}{l}\text { Czasopisma pedagogiczne w Polsce } \\
\text { (zarys problematyki) }\end{array}$ \\
\hline & & & Glogier Marek & $\begin{array}{l}\text { „Lud” - organ Polskiego Towarzystwa } \\
\text { Ludoznawczego }\end{array}$ \\
\hline & & & Toczek Alfred & $\begin{array}{l}\text { Krakowski dziennik PPS „Naprzód” } \\
\text { w latach 1919-1939 (zarys problematyki) }\end{array}$ \\
\hline & & & Bujak Jan & $\begin{array}{l}\text { Nieznany czerniowiecki tygodnik } \\
\text { w języku polskim }\end{array}$ \\
\hline & & & Bańdo Adam & $\begin{array}{l}\text { „Zrąb" - kwartalnik pedagogiczny } \\
\text { w latach 1930-1936 }\end{array}$ \\
\hline & & & $\begin{array}{l}\text { Woźniakowski } \\
\text { Krzysztof }\end{array}$ & $\begin{array}{l}\text { Gadzinowy miesięcznik „,Kolejowiec” } \\
\text { (1943-1944) i jego publikacje literackie }\end{array}$ \\
\hline 1998 , t. 9 & 11 & 1 & Szareyko Henryk & $\begin{array}{l}\text { Dwutygodnik „Ruch Chrześcijańsko- } \\
\text {-Społeczny” (Poznań 1902-1910). Cz. I }\end{array}$ \\
\hline \multirow[t]{2}{*}{ 2001, t. 1} & 11 & 2 & Bukowski Paweł & $\begin{array}{l}\text { Prasa NSZZ "Solidarnośćc" na ziemi } \\
\text { jasielskiej w latach 1981-1989 }\end{array}$ \\
\hline & & & $\begin{array}{l}\text { Kolasa Władysław } \\
\text { Marek }\end{array}$ & $\begin{array}{l}\text { Prasa komputerowa w Polsce - histo- } \\
\text { ria i statystyka }\end{array}$ \\
\hline \multirow[t]{5}{*}{2003 , t. 2} & 11 & 6 & Bańdo Adam & $\begin{array}{l}\text { „Ilustrowany Kurier Codzienny" } \\
\text { w dziewięćdziesiątą rocznicę powsta- } \\
\text { nia (1910-2000) }\end{array}$ \\
\hline & & & $\begin{array}{l}\text { Kolasa Władysław } \\
\text { Marek }\end{array}$ & $\begin{array}{l}\text { Epitafium dla „Czasu Krakowskiego" } \\
(1990-1997)\end{array}$ \\
\hline & & & Kwiecień Sabina & $\begin{array}{l}\text { Prasa żydowska w języku polskim } \\
\text { w Krakowie w latach 1918-1939 }\end{array}$ \\
\hline & & & $\begin{array}{l}\text { Woźniakowski } \\
\text { Krzysztof }\end{array}$ & $\begin{array}{l}\text { Gadzinowy „,katolicki organ prasowy } \\
\text { Generalnego Gubernatorstwa” w krę- } \\
\text { gu zagadnień kultury (1939-1945) }\end{array}$ \\
\hline & & & Seniów Jerzy & $\begin{array}{l}\text { Kultura legionowa w czasie pierwszej } \\
\text { wojny światowej na łamach prasy kra- } \\
\text { kowskiej w latach 1914-1918 }\end{array}$ \\
\hline
\end{tabular}




\begin{tabular}{|c|c|c|c|c|}
\hline 1 & 2 & 3 & 4 & 5 \\
\hline & & & Witczak Dorota & $\begin{array}{l}\text { Stefania Podhorska-Okołów - ostatnia } \\
\text { redaktorka „Bluszczu” }\end{array}$ \\
\hline \multirow[t]{5}{*}{2005, t. 3} & 14 & 5 & Jarowiecki Jerzy & $\begin{array}{l}\text { Lwowska prasa przed powstaniem } \\
\text { styczniowym }\end{array}$ \\
\hline & & & $\begin{array}{l}\text { Fogelzang-Adler } \\
\text { Ewa }\end{array}$ & $\begin{array}{l}\text { Sytuacja na frontach i polityka mię- } \\
\text { dzynarodowa w konspiracyjnych cza- } \\
\text { sopismach społeczno-kulturalnych } \\
\text { Krakowa okresu II wojny światowej }\end{array}$ \\
\hline & & & $\begin{array}{l}\text { Chwastyk-Kowal- } \\
\text { czyk Jolanta }\end{array}$ & $\begin{array}{l}\text { Muzyka i teatr na łamach londyń- } \\
\text { skiego "Dziennika Polskiego" w la- } \\
\text { tach } 1940-1943\end{array}$ \\
\hline & & & $\begin{array}{l}\text { Kolasa Władysław } \\
\text { Marek }\end{array}$ & $\begin{array}{l}\text { Krakowska prasa naukowa i fachowa } \\
\text { 1989-1998 (przegląd tematyczny) }\end{array}$ \\
\hline & & & Ludorowski Leszek & $\begin{array}{l}\text { Dokumenty życia społecznego odbi- } \\
\text { ciem rzeczywistości i zapisem historii }\end{array}$ \\
\hline \multirow[t]{3}{*}{2006, t. 4} & 11 & 3 & $\begin{array}{l}\text { Kolasa Władysław } \\
\text { Marek }\end{array}$ & $\begin{array}{l}\text { Krakowska prasa katolicka u schył- } \\
\text { ku XX w. }\end{array}$ \\
\hline & & & $\begin{array}{l}\text { Kolasa Władysław } \\
\text { Marek }\end{array}$ & $\begin{array}{l}\text { Krakowska prasa reklamowa i rekla- } \\
\text { ma na łamach krakowskiej prasy w la- } \\
\text { tach 1989-1998 }\end{array}$ \\
\hline & & & Bańdo Adam & $\begin{array}{l}\text { Obrazy kultury i literatury na łamach } \\
\text { "Ilustrowanego Kuriera Codzienne- } \\
\text { go" w latach 1918-1939 (wyniki ana- } \\
\text { lizy prasoznawczej) }\end{array}$ \\
\hline 2007 , t. 5 & 6 & 1 & Trojanowski Piotr & $\begin{array}{l}\text { Czasopismo „Znicz” (Kraków, 1930- } \\
\text { 1939) }\end{array}$ \\
\hline 2008 , t. 6 & 6 & 1 & $\begin{array}{l}\text { Chwastyk-Kowal- } \\
\text { czyk Jolanta }\end{array}$ & $\begin{array}{l}\text { Film na łamach londyńskiego „Dzien- } \\
\text { nika Polskiego i Dziennika Żołnierza” } \\
\text { w latach 1944-1989 }\end{array}$ \\
\hline \multirow[t]{3}{*}{2009, t. 7} & 11 & 3 & Kulka Bronisław & $\begin{array}{l}\text { Czytelnie, czytelnictwo i recepcja tek- } \\
\text { stów literackich w uczniowskich kra- } \\
\text { kowskich i lwowskich czasopismach } \\
\text { o tytule „Znicz” }\end{array}$ \\
\hline & & & $\begin{array}{l}\text { Lisowska-Kożuch } \\
\text { Urszula }\end{array}$ & $\begin{array}{l}\text { Instytucje związane z książką na ła- } \\
\text { mach „Dziennika Polskiego” w latach } \\
\text { 1945-1969. Część I. Biblioteki i archiwa }\end{array}$ \\
\hline & & & $\begin{array}{l}\text { Lisowska-Kożuch } \\
\text { Urszula }\end{array}$ & $\begin{array}{l}\text { Instytucje związane z książką na ła- } \\
\text { mach „Dziennika Polskiego" w latach } \\
\text { 1945-1969. Część II. Wydawnictwa } \\
\text { i księgarnie }\end{array}$ \\
\hline \multirow[t]{2}{*}{2010 , t. 8} & 13 & 2 & Zając Renata M. & $\begin{array}{l}\text { „Nie trzeba wyczerpywać całego te- } \\
\text { matu. Wystarczy przebudzić myśl". } \\
\text { Polskie czasopisma popularnonauko- } \\
\text { we o profilu humanistycznym w la- } \\
\text { tach 1945-1989 - zarys problemu }\end{array}$ \\
\hline & & & $\begin{array}{l}\text { Fogelzang-Adler } \\
\text { Ewa }\end{array}$ & $\begin{array}{l}\text { Działania Niemców wobec Polaków } \\
\text { w świetle konspiracyjnej prasy ugru- } \\
\text { powań demokratycznych (1939-1945) }\end{array}$ \\
\hline $\begin{array}{l}2012, \text { t. } 10- \\
2013, \text { t. } 11\end{array}$ & 22 & 0 & & \\
\hline
\end{tabular}




\begin{tabular}{|c|c|c|c|c|}
\hline 1 & 2 & 3 & 4 & 5 \\
\hline 2014, t. 12 & 11 & 1 & Zając Renata M. & $\begin{array}{l}\text { Czasopisma popularnonaukowe dla } \\
\text { dzieci w latach 1945-1989 }\end{array}$ \\
\hline \multirow[t]{12}{*}{2015, t. 13} & 14 & 12 & $\begin{array}{l}\text { Kolasa Władysław } \\
\text { Marek }\end{array}$ & $\begin{array}{l}\text { On the Statistics and Geography of the } \\
\text { Polish Press in the Period between the } \\
\text { Uprisings (1832-1864) }\end{array}$ \\
\hline & & & Kamisińska Dorota & $\begin{array}{l}\text { Grafika polskich tygodników ilustro- } \\
\text { wanych dla dzieci w drugiej połowie } \\
\text { XIX wieku na przykładzie warszaw- } \\
\text { skiego, lwowskiego i poznańskiego } \\
\text { „Przyjaciela Dzieci” }\end{array}$ \\
\hline & & & Toczek Alfred & $\begin{array}{l}\text { Czasopisma polskiej młodzieży aka- } \\
\text { demickiej w okresie popowstaniowym } \\
\text { (1865-1918). Przegląd informacyjno- } \\
\text {-bibliograficzny }\end{array}$ \\
\hline & & & $\begin{array}{l}\text { Woźniakowski } \\
\text { Krzysztof }\end{array}$ & $\begin{array}{l}\text { Pierwsze lata warszawskiego „Przyja- } \\
\text { ciela Dzieci”: w kręgu Fryderyka Hen- } \\
\text { ryka Lewestama i współpracowników } \\
\text { (kwiecień } 1861 \text { - czerwiec 1865) }\end{array}$ \\
\hline & & & Romanow Andrzej & $\begin{array}{l}\text { Polskie czasopisma młodzieżowe } \\
\text { w Wolnym Mieście Gdańsku }\end{array}$ \\
\hline & & & Zając Renata M. & $\begin{array}{l}\text { Galicyjski dodatek „Dla Młodszych” } \\
\text { (1898-1913) na tle polskich czasopism } \\
\text { popularnonaukowych }\end{array}$ \\
\hline & & & Kwiecień Sabina & $\begin{array}{l}\text { Kartka z dziejów żydowskiej prasy dla } \\
\text { dzieci i młodzieży w okresie autono- } \\
\text { mii Galicji }\end{array}$ \\
\hline & & & Lehmann Iwona & $\begin{array}{l}\text { Dodatki „Dziennika Berlińskiego” dla } \\
\text { dzieci i młodzieży w latach 1925-1939 }\end{array}$ \\
\hline & & & $\begin{array}{l}\text { Szabłowska-Zarem- } \\
\text { ba Monika }\end{array}$ & $\begin{array}{l}\text { "Okienko na Świat. Pismo dzieci } \\
\text { i młodzieży" 1937-1939 }\end{array}$ \\
\hline & & & $\begin{array}{l}\text { Nadolna-Tłuczykont } \\
\text { Marta }\end{array}$ & $\begin{array}{l}\text { Czasopisma dla dzieci wydawnictwa } \\
\text { Egmont Publishing }\end{array}$ \\
\hline & & & Maroń Agnieszka & $\begin{array}{l}\text { Szkice o współczesnych włoskich cza- } \\
\text { sopismach poświęconych literaturze } \\
\text { dziecięcej (włoska literatura dziecię- } \\
\text { ca w II połowie XX w.) }\end{array}$ \\
\hline & & & $\begin{array}{l}\text { Karczewska } \\
\text { Agnieszka }\end{array}$ & $\begin{array}{l}\text { Historia i struktura czasopisma } \\
\text { "Chwilka Dzieci i Młodzieży" }\end{array}$ \\
\hline \multirow[t]{3}{*}{2016, t. 14} & 26 & 3 & Kwiecień Sabina & $\begin{array}{l}\text { Poznańskie czasopisma dla dzieci } \\
\text { i młodzieży do } 1918 \text { roku }\end{array}$ \\
\hline & & & $\begin{array}{l}\text { Woźniakowski } \\
\text { Krzysztof }\end{array}$ & $\begin{array}{l}\text { Poligraf redaktorem: warszawski „Przy- } \\
\text { jaciel Dzieci” czasu redakcji Emila Skiw- } \\
\text { skiego (wrzesień } 1890 \text { - czerwiec 1892) }\end{array}$ \\
\hline & & & $\begin{array}{l}\text { Korczyńska-Derkacz } \\
\text { Małgorzata, } \\
\text { Łuszpak Agnieszka }\end{array}$ & $\begin{array}{l}\text { Hanna Krall w przestrzeni wydaw- } \\
\text { niczej i medialnej - analiza objętości } \\
\text { w pierwszym piętnastoleciu XXI w. }\end{array}$ \\
\hline łącznie & 238 & 67 & & \\
\hline
\end{tabular}

Źródło: obliczenia własne na podstawie analizy zawartości czasopism: „Rocznik Naukowo-Dydaktyczny. Prace Bibliotekoznawcze” oraz jego kontynuacji „Annales Universitatis Paedagogicae Cracoviensis Studia ad Bibliothecarum Scientiam Pertinentia" (1982-2016). 
Tabela 6

Czasopismo „Kieleckie Studia Bibliologiczne” wraz z kontynuacją „Studia Bibliologiczne Akademii Świętokrzyskiej” oraz „Rocznik Bibliologiczno-Prasoznawczy” (1993-2016)

\begin{tabular}{|c|c|c|c|c|}
\hline Rok, tom & $\begin{array}{l}\text { Ogólna } \\
\text { liczba art }\end{array}$ & $\begin{array}{l}\text { Liczba art. } \\
\text { prasozn. }\end{array}$ & Autor & Tytuł artykułu \\
\hline 1 & 2 & 3 & 4 & 5 \\
\hline \multirow{4}{*}{1993, t. 1} & \multirow{4}{*}{11} & \multirow{4}{*}{4} & $\begin{array}{l}\text { Adamczyk } \\
\text { Mieczysław }\end{array}$ & $\begin{array}{l}\text { Restrykcje wobec czasopiśmiennictwa } \\
\text { wyznaniowego na Kielecczyźnie w la- } \\
\text { tach stalinizacji kraju }\end{array}$ \\
\hline & & & $\begin{array}{l}\text { Adamska-Czerw } \\
\text { Jolanta }\end{array}$ & $\begin{array}{l}\text { Pisma samorządowe na Kielecczyźnie } \\
\text { w latach 1990-1992 }\end{array}$ \\
\hline & & & $\begin{array}{l}\text { Dzieniakowska } \\
\text { Jolanta }\end{array}$ & $\begin{array}{l}\text { Pisma szkolne w Radomiu w latach } \\
\text { 1918-1939 }\end{array}$ \\
\hline & & & $\begin{array}{l}\text { Gierszewska } \\
\text { Barbara }\end{array}$ & $\begin{array}{l}\text { Teatr a kino w świetle polskiej prasy } \\
\text { filmowej do roku } 1939\end{array}$ \\
\hline \multirow{4}{*}{1995, t. 2} & \multirow{4}{*}{11} & \multirow{4}{*}{4} & Mielczarek Tomasz & $\begin{array}{l}\text { Funkcje prasy w systemie politycz- } \\
\text { nym Drugiej Rzeczypospolitej }\end{array}$ \\
\hline & & & $\begin{array}{l}\text { Adamczyk } \\
\text { Mieczysław }\end{array}$ & $\begin{array}{l}\text { Prasa religijna Kielecczyzny w dwu- } \\
\text { dziestoleciu międzywojennym (Typo- } \\
\text { logia, funkcje, modele) }\end{array}$ \\
\hline & & & $\begin{array}{l}\text { Dzieniakowska } \\
\text { Jolanta }\end{array}$ & $\begin{array}{l}\text { Prasa polska w Radomiu 1918-1939. } \\
\text { Spis tytułów. Charakterystyka staty- } \\
\text { styczna }\end{array}$ \\
\hline & & & $\begin{array}{l}\text { Gierszewska } \\
\text { Barbara }\end{array}$ & $\begin{array}{l}\text { Czasopisma filmowe w Krakowie do } \\
\text { roku } 1939\end{array}$ \\
\hline \multirow[t]{2}{*}{1998, t. 3} & \multirow[t]{2}{*}{11} & \multirow[t]{2}{*}{2} & $\begin{array}{l}\text { Dzieniakowska } \\
\text { Jolanta }\end{array}$ & $\begin{array}{l}\text { Prasa Narodowej Demokracji w Rado- } \\
\text { miu w dwudziestoleciu międzywojen- } \\
\text { nym. Przegląd wydawnictw }\end{array}$ \\
\hline & & & Mielczarek Tomasz & Dwie „Rzeczpospolite” (1920-1932) \\
\hline \multirow{4}{*}{1998 , t. 4} & \multirow{4}{*}{11} & \multirow{4}{*}{4} & $\begin{array}{l}\text { Dzieniakowska } \\
\text { Jolanta }\end{array}$ & „Ziemia Radomska” (1928-1935) \\
\hline & & & Kaleta Andrzej & $\begin{array}{l}\text { Wydawcy polskiej prasy misyjnej } \\
\text { w latach 1918-1939 }\end{array}$ \\
\hline & & & Kępa Jolanta & $\begin{array}{l}\text { Twórcy prasy zakładowej Kielecczy- } \\
\text { zny (1945-1989) }\end{array}$ \\
\hline & & & Mielczarek Tomasz & $\begin{array}{l}\text { Polska prasa informacyjno-polityczna } \\
\text { w latach 1989-1996 }\end{array}$ \\
\hline \multirow{2}{*}{2000 , t. 5} & \multirow{2}{*}{8} & \multirow{2}{*}{2} & Mielczarek Tomasz & $\begin{array}{l}\text { Liberałowie i rewizjoniści. Z dziejów } \\
\text { „Przeglądu Kulturalnego” (1952-1963) }\end{array}$ \\
\hline & & & Sokół Zofia & $\begin{array}{l}\text { Czasopisma organizacji kobiecych } \\
\text { w Polsce w latach 1989-1999 }\end{array}$ \\
\hline \multirow{3}{*}{2001 , t. 6} & \multirow{3}{*}{9} & \multirow{3}{*}{3} & Sokół Zofia & $\begin{array}{l}\text { "Przyjaciółka" - tygodnik kobiecy } \\
\text { (1948-1998) }\end{array}$ \\
\hline & & & Mielczarek Tomasz & $\begin{array}{l}\text { Prasa w enuncjacjach programowych } \\
\text { i praktyce politycznej PZPR w latach } \\
\text { 1956-1989 }\end{array}$ \\
\hline & & & Pawelec Ewa & $\begin{array}{l}\text { Rola wydawnictw dla dzieci i mło- } \\
\text { dzieży w kreowaniu ról i postaw spo- } \\
\text { łeczno-ideowych. Opinie recenzentów } \\
\text { „Nowych Książek" z lat 70. XX w. }\end{array}$ \\
\hline
\end{tabular}




\begin{tabular}{|c|c|c|c|c|}
\hline 1 & 2 & 3 & 4 & 5 \\
\hline \multirow{5}{*}{2003, t. 7} & \multirow{5}{*}{9} & \multirow{5}{*}{5} & $\begin{array}{l}\text { Chwastyk-Kowal- } \\
\text { czyk Jolanta }\end{array}$ & $\begin{array}{l}\text { Oświata i wychowanie na łamach } \\
\text { „Bluszczu” w latach 1918-1939 }\end{array}$ \\
\hline & & & $\begin{array}{l}\text { Zielińska Nina, } \\
\text { Zieliński Konrad }\end{array}$ & $\begin{array}{l}\text { Prasowe inicjatywy wydawnicze To- } \\
\text { warzystwa straży Kresowej w latach } \\
1918-1922\end{array}$ \\
\hline & & & Piasecka Renata & $\begin{array}{l}\text { Agencja publicystyczno-Informacyj- } \\
\text { na (API) w latach 1944-1967 "Gaze- } \\
\text { ta dla gazet" }\end{array}$ \\
\hline & & & Sokół Zofia & $\begin{array}{l}\text { "Przyjaciółka" - tygodnik kobiecy } \\
\text { (część II: marzec 1951-marzec 1990) }\end{array}$ \\
\hline & & & Pawelec Ewa & $\begin{array}{l}\text { Wzorce ideowe propagowane na ła- } \\
\text { mach czasopism dla dzieci i młodzie- } \\
\text { ży w pierwszej połowie lat } 70 \text {. XX } \mathrm{W} \text {. }\end{array}$ \\
\hline \multirow{8}{*}{2004, t. 8} & \multirow{3}{*}{10} & \multirow{3}{*}{8} & $\begin{array}{l}\text { Kępa-Mętrak } \\
\text { Jolanta }\end{array}$ & $\begin{array}{l}\text { Reportaż w "Gazecie Kieleckiej" } \\
\text { w dwudziestoleciu międzywojen- } \\
\text { nym - próba analizy gatunku }\end{array}$ \\
\hline & & & $\begin{array}{l}\text { Chwastyk-Kowal- } \\
\text { czyk Jolanta }\end{array}$ & $\begin{array}{l}\text { Numery specjalne „Bluszczu' w okre- } \\
\text { sie dwudziestolecia międzywojenne- } \\
\text { go. Cześć I. }\end{array}$ \\
\hline & & & $\begin{array}{l}\text { Olczak-Kardas } \\
\text { Monika }\end{array}$ & $\begin{array}{l}\text { Wydawnictwa "Naszej Księgarni” } \\
\text { na łamach "Głosu Nauczycielskiego" } \\
\text { w latach 1921-1939. }\end{array}$ \\
\hline & & & $\begin{array}{l}\text { Woźniakowski } \\
\text { Krzysztof }\end{array}$ & $\begin{array}{l}\text { Niemiecka polskojęzyczna prasa „gadzi- } \\
\text { nowa" czasów II wojny światowej 1939- } \\
1945 \text { (próba syntetycznego spojrzenia) }\end{array}$ \\
\hline & & & Mielczarek Tomasz & $\begin{array}{l}\text { Konformiści czy buntownicy? Kilka } \\
\text { uwag o dziennikarzach i publicystach } \\
\text { Polski Ludowej (1945-1989) }\end{array}$ \\
\hline & & & Chrząstek Tomasz & $\begin{array}{l}\text { Przeciw rewizjonistom. Z dziejów } \\
\text { „Nowej Kultury" w latach 1958-1961 }\end{array}$ \\
\hline & & & Sokół Zofia & $\begin{array}{l}\text { „Przyjaciółka” - czasopismo dla ko- } \\
\text { biet (część III: „Przyjaciółka” w latach } \\
\text { 1989-2002 }\end{array}$ \\
\hline & & & $\begin{array}{l}\text { Dąbrowska-Cen- } \\
\text { drowska Olga }\end{array}$ & $\begin{array}{l}\text { Wydawnictwo „Burda Polska” w la- } \\
\text { tach 1990-2002 }\end{array}$ \\
\hline \multirow{7}{*}{ 2005, t. 9} & \multirow{7}{*}{9} & \multirow{7}{*}{7} & $\begin{array}{l}\text { Gierszewska } \\
\text { Barbara }\end{array}$ & Film i kino w lwowskiej prasie 1895-1918 \\
\hline & & & $\begin{array}{l}\text { Chwastyk-Kowal- } \\
\text { czyk Jolanta }\end{array}$ & $\begin{array}{l}\text { Numery specjalne „,Bluszczu’ w okre- } \\
\text { sie dwudziestolecia międzywojenne- } \\
\text { go. Cześć II }\end{array}$ \\
\hline & & & Sokół Zofia & „Kobieta i Życie” \\
\hline & & & Pawelec Ewa & $\begin{array}{l}\text { Czasopisma dla dzieci i młodzieży lat } \\
70 . \text { XX wieku narzędziem edukacji pa- } \\
\text { triotycznej }\end{array}$ \\
\hline & & & $\begin{array}{l}\text { Kępa-Mętrak } \\
\text { Jolanta }\end{array}$ & $\begin{array}{l}\text { Co w trawie piszczy? Charakterysty- } \\
\text { ka świętokrzyskich dzienników regio- } \\
\text { nalnych }\end{array}$ \\
\hline & & & $\begin{array}{l}\text { Dąbrowska-Cen- } \\
\text { drowska Olga }\end{array}$ & $\begin{array}{l}\text { Działalność wydawnicza koncer- } \\
\text { nu „Axel Springer Polska” w latach } \\
1994-2003\end{array}$ \\
\hline & & & Pokrzycka Lidia & $\begin{array}{l}\text { Lubelska prasa bezpłatna } \mathrm{w} \text { latach } \\
\text { 1992-2004 }\end{array}$ \\
\hline
\end{tabular}




\begin{tabular}{|c|c|c|c|c|}
\hline 1 & 2 & 3 & 4 & 5 \\
\hline \multirow{4}{*}{ 2006, t. 10} & \multirow{4}{*}{7} & \multirow{4}{*}{4} & Jarowiecki Jerzy & $\begin{array}{l}\text { Maria Konopnicka w polskiej prasie } \\
\text { konspiracyjnej i poza krajem w latach } \\
\text { 1939-1945 }\end{array}$ \\
\hline & & & Kaleta Andrzej & $\begin{array}{l}\text { "Przegląd Powszechny" 1884-2005. } \\
\text { Charakterystyka i stan badań }\end{array}$ \\
\hline & & & $\begin{array}{l}\text { Chwastyk-Kowal- } \\
\text { czyk Jolanta }\end{array}$ & $\begin{array}{l}\text { Powstanie i rozwój „Dziennika pol- } \\
\text { skiego” w latach 1940-1943 }\end{array}$ \\
\hline & & & Mielczarek Tomasz & Telewizja „Polsat” Zygmunta Solorza \\
\hline \multirow{7}{*}{2008, t. 11} & \multirow{7}{*}{11} & \multirow{7}{*}{7} & $\begin{array}{l}\text { Szornel-Dąbrowska } \\
\text { Barbara }\end{array}$ & $\begin{array}{l}\text { "Wiadomości Brukowe" - próba kon- } \\
\text { tynuacji idei czasopisma Towarzystwa } \\
\text { Szubrawców w Wilnie }\end{array}$ \\
\hline & & & $\begin{array}{l}\text { Korczyńska-Der- } \\
\text { kacz Małgorzata }\end{array}$ & $\begin{array}{l}\text { "Biblioteka Warszawska" (1841-1914) } \\
\text { źródłem wiedzy o krajowym i zagra- } \\
\text { nicznym ruchu naukowym }\end{array}$ \\
\hline & & & $\begin{array}{l}\text { Czarnik Oskar } \\
\text { Stanisław }\end{array}$ & $\begin{array}{l}\text { Czasopismo „Polska” w ZSRR (1941- } \\
\text { 1943). Trudna praca na osamotnionym } \\
\text { posterunku }\end{array}$ \\
\hline & & & $\begin{array}{l}\text { Chwastyk-Kowal- } \\
\text { czyk Jolanta }\end{array}$ & $\begin{array}{l}\text { Jan Czarnocki - redaktor naczelny lon- } \\
\text { dyńskiego „Dziennika polskiego i Dzien- } \\
\text { nika Żołnierza” w latach 1945-1957 }\end{array}$ \\
\hline & & & Chrzastek Tomasz & $\begin{array}{l}\text { Ilościowa analiza zawartości prasy na } \\
\text { przykładzie tygodnika społeczno-kul- } \\
\text { turalnego „Nowa Kultura” }\end{array}$ \\
\hline & & & $\begin{array}{l}\text { Dzieniakowska } \\
\text { Jolanta }\end{array}$ & $\begin{array}{l}\text { Inicjatywy prasowo-wydawnicze } \\
\text { uczniów. Miedzy autoprezentacją } \\
\text { a integracją }\end{array}$ \\
\hline & & & Mielczarek Tomasz & $\begin{array}{l}\text { Od Ciężko rannych pantofli po taniec } \\
\text { z gwiazdami. Telewizja TVN w latach } \\
\text { 1996-2006 }\end{array}$ \\
\hline \multirow{4}{*}{2009, t. $1 / 12$} & \multirow{4}{*}{7} & \multirow{4}{*}{4} & Siuda Maria M. & $\begin{array}{l}\text { Ingerencje cenzorskie jako narzędzie } \\
\text { reglamentowania treści prasowych (na } \\
\text { przykładzie prasy kieleckiej) }\end{array}$ \\
\hline & & & Mielczarek Tomasz & $\begin{array}{l}\text { Festiwal „Solidarności” i stan wojen- } \\
\text { ny na łamach czasopism społeczno- } \\
\text {-kulturalnych PRL }\end{array}$ \\
\hline & & & Centek Barbara & $\begin{array}{l}\text { Popularnonaukowe czasopisma po- } \\
\text { łudniowo-wschodniego Podlasia } \\
(1980-2005)\end{array}$ \\
\hline & & & Dzierżyński Jolanta & $\begin{array}{l}\text { Odwrót od lokalności [rozwój prasy } \\
\text { lokalnej od 1989-1994] }\end{array}$ \\
\hline \multirow{4}{*}{2010 , t. $2 / 13$} & \multirow{4}{*}{14} & \multirow{4}{*}{12} & Hombek Danuta & $\begin{array}{l}\text { O potrzebie nowej bibliografii pol- } \\
\text { skich gazet i czasopism XVIII w. }\end{array}$ \\
\hline & & & Kęder Wojciech & $\begin{array}{l}\text { "Gazeta Warszawska" wobec wojny } \\
\text { o niepodległość Stanów Zjednoczo- } \\
\text { nych w latach } 1778-1782\end{array}$ \\
\hline & & & Uljasz Adrian & $\begin{array}{l}\text { Czasopisma wyznaniowe na straży } \\
\text { polskości. Z przeszłości prasy lute- } \\
\text { rańskiej i kalwińskiej do } 1939 \text { r. }\end{array}$ \\
\hline & & & Siuda Maria M. & $\begin{array}{l}\text { Kolportaż oraz upowszechnianie pra- } \\
\text { sy na Kielecczyźnie w latach 1945-1952 }\end{array}$ \\
\hline
\end{tabular}




\begin{tabular}{|c|c|c|c|c|}
\hline 1 & 2 & 3 & 4 & 5 \\
\hline \multirow{8}{*}{2010, t. $2 / 13$} & \multirow{3}{*}{14} & \multirow{3}{*}{12} & $\begin{array}{l}\text { Nieć Grzegorz, } \\
\text { Pleszczyński Michał }\end{array}$ & $\begin{array}{l}\text { Problemy wrocławskiej gastrono- } \\
\text { mii w drugiej połowie lat } 60 \text {. XX w. } \\
\text { w świetle doniesień i komentarzy pra- } \\
\text { sowych }\end{array}$ \\
\hline & & & $\begin{array}{l}\text { Piasecka-Strzelec } \\
\text { Renata }\end{array}$ & $\begin{array}{l}\text { Służby prasowo-informacyjne w Pol- } \\
\text { sce w latach 1945-1971 }\end{array}$ \\
\hline & & & Mielczarek Tomasz & $\begin{array}{l}\text { Literatura i historia na łamach cza- } \\
\text { sopism RSW wydawanych w latach } \\
\text { 80. XX w. }\end{array}$ \\
\hline & & & Rygiel Beata & $\begin{array}{l}\text { „Niedziela" i „,Gość Niedzielny” jako } \\
\text { przykład tygodników katolickich }\end{array}$ \\
\hline & & & $\begin{array}{l}\text { Dąbrowska-Cen- } \\
\text { drowska Olga }\end{array}$ & $\begin{array}{l}\text { Wszystkie dzieci są nasze. Współcze- } \\
\text { sne polskie czasopisma przeznaczo- } \\
\text { ne dla rodziców. Próba analizy oferty } \\
\text { wydawniczej }\end{array}$ \\
\hline & & & Żabiński Ryszard & $\begin{array}{l}\text { Strategiczny model marketingowy } \\
\text { dziennika regionalnego i tygodnika } \\
\text { bezpłatnego }\end{array}$ \\
\hline & & & $\begin{array}{l}\text { Chwastyk-Kowal- } \\
\text { czyk Jolanta }\end{array}$ & Świat bez granic \\
\hline & & & $\begin{array}{l}\text { Wygodnik-Barzyk } \\
\text { Edyta }\end{array}$ & $\begin{array}{l}\text { „Polski Herald" i jego obecność na } \\
\text { rynku prasy polskiej w Irlandii w la- } \\
\text { tach 2005-2009 }\end{array}$ \\
\hline \multirow{7}{*}{2012, t. $3 / 14$} & \multirow{7}{*}{12} & \multirow{7}{*}{7} & Kęder Wojciech & $\begin{array}{l}\text { "Gazeta Warszawska" wobec wojny } \\
\text { o niepodległość Stanów Zjednoczo- } \\
\text { nych w latach 1778-1782 }\end{array}$ \\
\hline & & & Rogoż Michał & $\begin{array}{l}\text { „Tygodnik Powszechny" w } 1949 \text { r. } \\
\text { w świetle wtórnych ocen cenzorów } \\
\text { Głównego Urzędu Kontroli Prasy Pu- } \\
\text { blikacji i Widowisk }\end{array}$ \\
\hline & & & Uljasz Adrian & $\begin{array}{l}\text { Prasa regionalna jako nośnik propa- } \\
\text { gandy stalinowskiej. „Nowiny Rze- } \\
\text { szowskie” o śmierci Józefa Stalina }\end{array}$ \\
\hline & & & Mielczarek Tomasz & $\begin{array}{l}\text { Pod presją polityki. Nowelizacje usta- } \\
\text { wy o radiofonii telewizji }\end{array}$ \\
\hline & & & $\begin{array}{l}\text { Dąbrowska-Cen- } \\
\text { drowska Olga }\end{array}$ & $\begin{array}{l}\text { „Męska sprawa" - czyli zaangażowa- } \\
\text { nie niemieckich koncernów w seg- } \\
\text { ment prasy dla mężczyzn }\end{array}$ \\
\hline & & & $\begin{array}{l}\text { Gajlewicz-Korab } \\
\text { Katarzyna }\end{array}$ & $\begin{array}{l}\text { Specyfika mediów przeznaczonych } \\
\text { dla muzułmanów we Francji }\end{array}$ \\
\hline & & & Moraczewska Marta & $\begin{array}{l}\text { Al Jazeera - taniec międzykulturowe- } \\
\text { go niezrozumienia. Studium z socjolo- } \\
\text { gii komunikacji }\end{array}$ \\
\hline $\begin{array}{l}2012, \text { t. } 4 / 15, \\
\text { z. } 1\end{array}$ & 8 & 1 & $\begin{array}{l}\text { Chwastyk-Kowal- } \\
\text { czyk Jolanta }\end{array}$ & $\begin{array}{l}\text { Polska literatura zsyłkowa ogniwem } \\
\text { pomiędzy rodakami na uchodźstwie } \\
\text { i w kraju w świetle doniesień pra- } \\
\text { sowych }\end{array}$ \\
\hline $\begin{array}{l}\text { 2012, t. 4/15, } \\
\text { z. 2; }\end{array}$ & 11 & 0 & & $\begin{array}{l}\text { Całość numeru poświęcona polskie- } \\
\text { mu systemowi medialnemu }\end{array}$ \\
\hline
\end{tabular}




\begin{tabular}{|c|c|c|c|c|}
\hline 1 & 2 & 3 & 4 & 5 \\
\hline \multirow{5}{*}{2013, t. 5/16, } & \multirow{5}{*}{11} & \multirow{5}{*}{5} & $\begin{array}{l}\text { Gajlewicz-Korab } \\
\text { Katarzyna }\end{array}$ & $\begin{array}{l}\text { Funkcjonowanie francuskich środków } \\
\text { masowego przekazu w czasie prezy- } \\
\text { dentury Nicolasa Sarkozy'ego }\end{array}$ \\
\hline & & & $\begin{array}{l}\text { Chwastyk-Kowal- } \\
\text { czyk Jolanta }\end{array}$ & $\begin{array}{l}\text { Rynek czasopism literacko-artystycz- } \\
\text { nych w Polsce po } 1989 \text { r. }\end{array}$ \\
\hline & & & $\begin{array}{l}\text { Dąbrowska-Cen- } \\
\text { drowska Olga }\end{array}$ & $\begin{array}{l}\text { Wysokonakładowe magazyny lifesty- } \\
\text { lowe w Polsce w pierwszej dekadzie } \\
\text { XXI w. - kryzys, strategia czy rozwój? }\end{array}$ \\
\hline & & & Lis Wojciech & $\begin{array}{l}\text { Procedura rejestracji tytułu prasowe- } \\
\text { go. Problemy regulacyjne }\end{array}$ \\
\hline & & & Górski Adam & $\begin{array}{l}\text { Odpowiedzialności dziennikarza za } \\
\text { materiał prasowy - różnice pomiędzy } \\
\text { zniesławieniem a ochroną dóbr osobi- } \\
\text { stych (uwagi praktyczne) }\end{array}$ \\
\hline \multirow{5}{*}{2014, t. $6 / 17$} & \multirow{5}{*}{15} & \multirow{5}{*}{5} & Fiut Ignacy S. & $\begin{array}{l}\text { Migracja prasy bezpłatnej do Interne- } \\
\text { tu i jej strategie wydawnicze }\end{array}$ \\
\hline & & & $\begin{array}{l}\text { Dąbrowska-Cen- } \\
\text { drowska Olga }\end{array}$ & $\begin{array}{l}\text { Nowe kanały dystrybucji treści wy- } \\
\text { branych magazynów wysokonakła- } \\
\text { dowych i programów śniadaniowych }\end{array}$ \\
\hline & & & $\begin{array}{l}\text { Anculewicz } \\
\text { Zbigniew }\end{array}$ & $\begin{array}{l}\text { Dziennik opinii środowiska „krytyki } \\
\text { politycznej” - przykład migracji nowej } \\
\text { prasy do cyberprzestrzeni }\end{array}$ \\
\hline & & & Kubik Justyna & $\begin{array}{l}\text { Usieciowienie prasy lokalnej przymus } \\
\text { cyberkulturowy czy możliwość posze- } \\
\text { rzania oferty wydawniczej? }\end{array}$ \\
\hline & & & $\begin{array}{l}\text { Wasilewski } \\
\text { Krzysztof }\end{array}$ & $\begin{array}{l}\text { Wpływ nowych mediów na lokalny } \\
\text { rynek prasy, radia i telewizji przykład } \\
\text { subregionu gorzowskiego }\end{array}$ \\
\hline \multirow{5}{*}{2015, t. $7 / 18$} & \multirow{5}{*}{11} & \multirow{5}{*}{5} & Wojsław Jacek & $\begin{array}{l}\text { Kierownictwo partyjne wobec prasy } \\
\text { w Polsce w latach kulminacji stalini- } \\
\text { zmu (1949-1953): polityka personalna, } \\
\text { decyzje organizacyjne i „nastawianie” } \\
\text { tematyczne }\end{array}$ \\
\hline & & & $\begin{array}{l}\text { Suławka Adam } \\
\text { Radosław }\end{array}$ & $\begin{array}{l}\text { Prasa rosyjskojęzyczna wydawana w ło- } \\
\text { dzi przed I wojną światową w świetle } \\
\text { raportów cenzora Wasilija Pietrowa }\end{array}$ \\
\hline & & & $\begin{array}{l}\text { Dąbrowska-Cen- } \\
\text { drowska Olga }\end{array}$ & $\begin{array}{l}\text { Ludzkie historie dobrze się sprzedają. } \\
\text { Magazyny typu true story - charakte- } \\
\text { rystyka segmentu prasowego }\end{array}$ \\
\hline & & & $\begin{array}{l}\text { Chwastyk-Kowal- } \\
\text { czyk Jolanta }\end{array}$ & $\begin{array}{l}\text { Współczesny rynek czasopism o sztu- } \\
\text { ce w Polsce. Przegląd wydawnictw }\end{array}$ \\
\hline & & & $\begin{array}{l}\text { Wasilewski } \\
\text { Krzysztof }\end{array}$ & $\begin{array}{l}\text { Obraz emigracji niepodległościowej } \\
\text { w „Gazecie Wyborczej” (1989-1991) }\end{array}$ \\
\hline \multirow{2}{*}{2016 , t. $8 / 19$} & \multirow{2}{*}{17} & \multirow{2}{*}{6} & Ciszek Przemysław & $\begin{array}{l}\text { Czasopisma o grach wideo w Pol- } \\
\text { sce. Rys historyczny i obecna sytua- } \\
\text { cja na rynku }\end{array}$ \\
\hline & & & $\begin{array}{l}\text { Dąbrowska-Cen- } \\
\text { drowska Olga }\end{array}$ & $\begin{array}{l}\text { Tabloidyzacja luksusowych magazy- } \\
\text { nów dla kobiet i mężczyzn. Aspekt } \\
\text { ilościowy }\end{array}$ \\
\hline
\end{tabular}




\begin{tabular}{|c|c|c|l|l|}
\hline 1 & 2 & 3 & \multicolumn{1}{c|}{4} & \multicolumn{1}{c|}{5} \\
\hline \multirow{2}{*}{ 2016, t. 8/19 } & \multirow{2}{*}{17} & \multirow{2}{*}{6} & $\begin{array}{l}\text { Przybysz-Stawska } \\
\text { Magdalena }\end{array}$ & $\begin{array}{l}\text { „Fakt” kulturalny: oferta karnetu kul- } \\
\text { turalnego w latach 2010-2014 }\end{array}$ \\
\cline { 4 - 5 } & & Mielczarek Tomasz & Tabloidyzacja prasy opinii \\
\cline { 3 - 5 } & & Lis Wojciech & $\begin{array}{l}\text { Prasa internetowa. Proces migracji me- } \\
\text { diów do cyberprzestrzeni }\end{array}$ \\
\cline { 3 - 5 } & 213 & 95 & Kasiak Mateusz & $\begin{array}{l}\text { Artykuł publicystyczny w prasie } \\
\text { i w Internecie. Analiza porównawcza }\end{array}$ \\
\hline łącznie & & & \\
\hline
\end{tabular}

Źródło: obliczenia własne na podstawie analizy zawartości czasopism: „Kieleckie Studia Bibliologiczne", „,Studia Bibliologiczne Akademii Świętokrzyskiej” oraz „, Rocznik Bibliologiczno-Prasoznawczy" (1993-2016).

„Rocznik Bibliologiczno-Prasoznawczy”, o czym informowała redakcja: „(...) nazwa czasopisma lepiej informuje o jego zawartości. Już od 1993 r. umieszczano $\mathrm{w}$ nim bowiem teksty dotyczące szeroko pojmowanej wiedzy z zakresu nauk bibliologicznych i prasoznawstwa, chociaż ten drugi obszar badawczy nie był odzwierciedlony w tytule. [...] Chęć współpracy wyrazili przedstawiciele niemal wszystkich ośrodków prowadzących badania bibliologiczne i prasoznawcze (...) (Rocznik Bibliologiczno-Prasoznawczy [online], [dostęp: 25.04.2017]. Dostępny w WWW: <http://idi.ujk.edu. $\mathrm{pl} /$ studia/index.php>.). Po zmianie tytułu udział artykułów poświęconych zagadnieniom prasy spadł do $43,84 \%$, przy jednoczesnym wzroście zainteresowania autorów tematami z zakresu medioznawstwa, które - obok prasoznawstwa - rozwija się dynamicznie. Problemom polskiego systemu medialnego poświęcony był cały numer 2 z $2012 \mathrm{r}$.

Najmłodsze czasopismo, wychodzące od 2008 r., to półrocznik „Toruńskie Studia Bibliologiczne", który w założeniu redakcji „,...] ma służyć szerokim kręgom bibliologicznym i stanowić pewnego rodzaju platformę prezentacji własnych dokonań naukowych oraz forum wymiany doświadczeń i dyskusji. Do publikacji przyjmowane są artykuły poruszające zagadnienia od szeroko pojętego księgoznawstwa (ruch wydawniczy, introligatorstwo, grafika książkowa, cenzura, kolekcjonerstwo, sztuka ekslibrisu), po informatologię (działalność informacyjna bibliotek i ośrodków informacji, nowe technologie w nauce o informacji, zautomatyzowane systemy wyszukiwania informacji, sieć Internet i zasoby cyfrowe)" (Toruńskie Studia Bibliologiczne [online], [dostęp: 25.04.2017]. Dostępny w WWW: <http://www. home.umk.pl/ tsb/?q=pl/>.).Tematyka prasoznawcza była obecna w 20\% wszystkich opublikowanych artykułów. Autorzy interesowali się przede wszystkim czasopiśmiennictwem regionu kujawsko-pomorskiego, zarówno w aspekcie historycznym, jak i współczesnym, pojawiały się opracowania monograficzne poszczególnych tytułów bądź charakterystyki wybranych elementów zawartości prasy, np. reklam. 
Czasopismo „Toruńskie Studia Bibliologiczne” (2008-2016)

\begin{tabular}{|c|c|c|c|c|}
\hline Rok, numer & $\begin{array}{l}\text { Ogólna } \\
\text { liczba art }\end{array}$ & $\begin{array}{c}\text { Liczba art. } \\
\text { prasozn. }\end{array}$ & Autor & Tytuł artykułu \\
\hline 1 & 2 & 3 & 4 & 5 \\
\hline \multirow{3}{*}{2008, nr 1} & \multirow{3}{*}{13} & \multirow{3}{*}{3} & Kruszewski Tomasz & $\begin{array}{l}\text { Współczesna prasa mniejszości etnicz- } \\
\text { nych w Polsce w przestrzeni społecz- } \\
\text { nej- wybrane obszary }\end{array}$ \\
\hline & & & Centek Barbara & $\begin{array}{l}\text { Czasopisma naukowe Filii AWF } \\
\text { w Białej Podlaskiej w latach 1973-2002 }\end{array}$ \\
\hline & & & Żynda Marcin & $\begin{array}{l}\text { "Drukarz Pomorski" (1933-1939) jako } \\
\text { narzędzie kształtowania świadomoś- } \\
\text { ci i właściwych postaw drukarzy oraz } \\
\text { wzmacniania ich Związku Zawodowego }\end{array}$ \\
\hline \multirow{2}{*}{$\begin{array}{l}2009 \\
\operatorname{nr} 1(2)\end{array}$} & \multirow{2}{*}{9} & \multirow{2}{*}{2} & $\begin{array}{l}\text { Chwastyk-Kowal- } \\
\text { czyk Jolanta }\end{array}$ & $\begin{array}{l}\text { Recenzje polskich książek literackich } \\
\text { na łamach londyńskiego „Dziennika } \\
\text { Polskiego" w latach 1940-1943 }\end{array}$ \\
\hline & & & Jazownik Maria & $\begin{array}{l}\text { Przeciw radykalizmowi młodzieży } \\
\text { akademickiej. O konfiskacie i likwi- } \\
\text { dacji krakowskiego „Ruchu” (1891) }\end{array}$ \\
\hline $\begin{array}{l}2009 \\
\text { nr } 2(3)\end{array}$ & 9 & 1 & Kristanova Evelina & $\begin{array}{l}\text { Reklama książki na łamach „Rodziny } \\
\text { Polskiej' (1927-1939) }\end{array}$ \\
\hline \multirow{4}{*}{$\begin{array}{l}\text { 2010, } \\
\operatorname{nr} 1(4)\end{array}$} & \multirow{4}{*}{8} & \multirow{4}{*}{4} & Lempart Matthias & $\begin{array}{l}\text { Zapomniane bądź nieznane tytu- } \\
\text { ły prasowe z terenu Pomorza do } \\
\text { 1918/1939 r. }\end{array}$ \\
\hline & & & $\begin{array}{l}\text { Gorczyńska } \\
\text { Małgorzata }\end{array}$ & $\begin{array}{l}\text { „Kalendarz Lubelski” z lat 1958-1985 } \\
\text { (tak zwana druga edycja) }\end{array}$ \\
\hline & & & Szymoniak Krzysztof & $\begin{array}{l}\text { Rekonstrukcja zdarzeń, czyli począ- } \\
\text { tek niezależnego dziennikarstwa i pra- } \\
\text { sy lokalnej w Wielkopolsce po } 1989 \text { r. } \\
\text { na przykładzie „Tygodnika Kępińskie- } \\
\text { go" (część 1) }\end{array}$ \\
\hline & & & Marcol Anna & $\begin{array}{l}\text { „Kolano" (1995-2001) - czasopismo li- } \\
\text { teracko-kulturalne z Berlina }\end{array}$ \\
\hline \multirow{3}{*}{$\begin{array}{l}\text { 2010, } \\
\text { nr } 2(5)\end{array}$} & \multirow{3}{*}{10} & \multirow{3}{*}{3} & Wodniak Katarzyna & $\begin{array}{l}\text { Funkcje przekazów literackich i kry- } \\
\text { tycznych w czasopismach kobie- } \\
\text { cych (na przykładzie miesięcznika } \\
\text { „Bluszcz”, 2008-) }\end{array}$ \\
\hline & & & Kamisińska Dorota & $\begin{array}{l}\text { Warszawski tygodnik „Wędrowiec" } \\
\text { w latach 1863-1883 (część 1) }\end{array}$ \\
\hline & & & Szymoniak Krzysztof & $\begin{array}{l}\text { Rekonstrukcja zdarzeń, czyli począ- } \\
\text { tek niezależnego dziennikarstwa i pra- } \\
\text { sy lokalnej Wielkopolsce po } 1989 \text { r. na } \\
\text { przykładzie „Tygodnika Kępińskiego” } \\
\text { (część 2) }\end{array}$ \\
\hline $\begin{array}{l}\text { 2011, nr } 1 \\
\text { (6) }\end{array}$ & 7 & 4 & Albińska Jolanta & $\begin{array}{l}\text { Procesy prasowe redaktora „Dzienni- } \\
\text { ka Kujawskiego" Józefa Chociszew- } \\
\text { skiego z lat 1893-1896 }\end{array}$ \\
\hline
\end{tabular}




\begin{tabular}{|c|c|c|c|c|}
\hline 1 & 2 & 3 & 4 & 5 \\
\hline \multirow{3}{*}{$\begin{array}{l}\text { 2011, } \\
\text { nr } 1(6)\end{array}$} & \multirow{3}{*}{7} & \multirow{3}{*}{4} & Kamisińska Dorota & $\begin{array}{l}\text { Warszawski tygodnik „Wędrowiec" } \\
\text { w latach 1863-1883 (część 2) }\end{array}$ \\
\hline & & & $\begin{array}{l}\text { Smużewska Marce- } \\
\text { lina }\end{array}$ & $\begin{array}{l}\text { Studencki ruch naukowy na łamach } \\
\text { „Głosu Uczelni" }\end{array}$ \\
\hline & & & $\begin{array}{l}\text { Bertman Wisława, } \\
\text { Sokół Aneta }\end{array}$ & $\begin{array}{l}\text { Książka i prasa ewangelicka w Polsce po } \\
1989 \text { r. Zarys zagadnienia i stan badań }\end{array}$ \\
\hline \multirow{3}{*}{$\begin{array}{l}\text { 2011, } \\
\text { nr } 2(7)\end{array}$} & \multirow{3}{*}{8} & \multirow{3}{*}{3} & Kristanova Evelina & $\begin{array}{l}\text { "Acta universitatis Lodziensis. Folia } \\
\text { Librorum" (1989-2009) - ogólna cha- } \\
\text { rakterystyka wydawnictwa }\end{array}$ \\
\hline & & & $\begin{array}{l}\text { Zmitrowska Małgo- } \\
\text { rzata, Weryho Maciej }\end{array}$ & $\begin{array}{l}\text { Wykorzystanie baz danych oraz czaso- } \\
\text { pism elektronicznych przez pracowni- } \\
\text { ków naukowych na przykładzie badań } \\
\text { przeprowadzonych na Uniwersytecie } \\
\text { Kazimierza Wielkiego w Bydgoszczy }\end{array}$ \\
\hline & & & Fura Anita & $\begin{array}{l}\text { „British Museum Studiem in Ancien } \\
\text { Egipt and Sudan” jako przykład cza- } \\
\text { sopisma naukowego w wersji elektro- } \\
\text { nicznej - komunikat z badań }\end{array}$ \\
\hline $\begin{array}{l}2012 \\
\text { nr } 1(8)\end{array}$ & 8 & 1 & $\begin{array}{l}\text { Gromniak Małgo- } \\
\text { rzata }\end{array}$ & $\begin{array}{l}\text { Rola biblioterapeuty w pracy z oso- } \\
\text { bami współuzależnionymi - analiza } \\
\text { treści kwartalnika „Biblioterapeuta" } \\
\text { w latach 1998-2008 }\end{array}$ \\
\hline \multirow[t]{2}{*}{$\begin{array}{l}2012 \\
\operatorname{nr} 2(9)\end{array}$} & 10 & 2 & Edwardczyk Joanna & $\begin{array}{l}\text { Prasa Tucholi w latach 1920-1939 } \\
\text { (część 1) }\end{array}$ \\
\hline & & & Ciszewska Wanda A. & $\begin{array}{l}\text { Efemeryda wydawnicza toruńskiego } \\
\text { drukarza - Ćwierćpetit z roku } 1953\end{array}$ \\
\hline $\begin{array}{l}\text { 2013, } \\
\text { nr } 1(10)\end{array}$ & 8 & 1 & Edwardczyk Joanna & $\begin{array}{l}\text { Prasa Tucholi w latach 1920-1939 } \\
\text { (część 2) }\end{array}$ \\
\hline \multirow{2}{*}{$\begin{array}{l}2013 \\
\text { nr } 2(11)\end{array}$} & \multirow{2}{*}{10} & \multirow{2}{*}{2} & Gzella Grażyna & $\begin{array}{l}\text { Kłopoty z prawem zapomnianych ga- } \\
\text { zet pomorskich (1910-1915) }\end{array}$ \\
\hline & & & Ruta Adam & $\begin{array}{l}\text { Jednodniówki w systemie krakowskiej } \\
\text { cenzury w latach 1923-1939 }\end{array}$ \\
\hline \multirow{2}{*}{$\begin{array}{l}\text { 2014, } \\
\text { nr } 1(12)\end{array}$} & \multirow{2}{*}{9} & \multirow{2}{*}{2} & Żynda Marcin & $\begin{array}{l}\text { „Tętent. Miesięcznik Szkoły Podchorą- } \\
\text { żych Kawalerii w Grudziądzu” (1933- } \\
\text { 1934) }\end{array}$ \\
\hline & & & Wodniak Katarzyna & $\begin{array}{l}\text { W kręgu literatury kobiecej; konteksty } \\
\text { kultury książki w luksusowych maga- } \\
\text { zynach dla pań }\end{array}$ \\
\hline $\begin{array}{l}\text { 2014, } \\
\text { nr } 2 \text { (13) }\end{array}$ & 9 & 1 & Kamińska Jolanta & $\begin{array}{l}\text { Katowickie "Studia Bibliologiczne" } \\
(1983-2011) \text { - próba charakterystyki } \\
\text { wydawnictwa }\end{array}$ \\
\hline $\begin{array}{l}\text { 2015, } \\
\text { nr } 1(14)\end{array}$ & 6 & 1 & Kamisińska Dorota & $\begin{array}{l}\text { Dessiné et gravé... Francuskie drze- } \\
\text { woryty w polskich tygodnikach ilu- } \\
\text { strowanych XIX w. na przykładzie } \\
\text { tygodnika „Wędrowiec" (część II) }\end{array}$ \\
\hline $\begin{array}{l}2015 \\
\text { nr } 2(15)\end{array}$ & 9 & 1 & Wojtacki Maciej & $\begin{array}{l}\text { „Na Dobie”. Monografia zapomnia- } \\
\text { nego tygodnika konserwatywnego } \\
\text { z okresu międzywojennego }\end{array}$ \\
\hline
\end{tabular}




\begin{tabular}{|l|c|c|l|l|}
\hline \multicolumn{1}{|c|}{1} & 2 & 3 & 4 & \multicolumn{1}{c|}{5} \\
\hline $\begin{array}{l}2016, \\
\text { nr 1 (16) }\end{array}$ & 6 & 1 & Gzella Grażyna & $\begin{array}{l}\text { Kościańskie, lwowskie i poznańskie } \\
\text { losy Sylwestra Czarneckiego }\end{array}$ \\
\hline $\begin{array}{l}2016, \\
\text { nr 2 (17) }\end{array}$ & 6 & 0 & & \\
\hline łącznie & 145 & 32 & & \\
\hline
\end{tabular}

Źródło: obliczenia własne na podstawie analizy zawartości czasopisma „Toruńskie Studia Bibliologiczne" (2008-2016)

\section{WNIOSKI}

W analizowanych czasopismach naukowych artykuły opublikowało 157 autorów, z czego 104 - po jednym artykule, dwudziestu ośmiu - po 2 artykuły, dziesięciu - po 3, czterech autorów - po 4, trzech - 5 artykułów, dwóch -6 , jeden -7 , jeden -8 , jeden -10 , dwóch autorów po 12 artykułów i jedna autorka - 15 artykułów.

Najwięcej artykułów napisała $\mathrm{H}$. Tadeusiewicz, związana z ośrodkiem łódzkim. Swoje prace poświęcone zawodowym periodykom drukarzy i litografów publikowała przede wszystkim w „Rocznikach Bibliotecznych" (jeden artykuł w „Z Badań nad Polskimi Księgozbiorami Historycznymi").

Tabela 8

Autorzy, którzy zamieścili więcej niż 4 artykuły w analizowanych czasopismach

\begin{tabular}{|l|l|c|}
\hline \multicolumn{1}{|c|}{ L.p. } & \multicolumn{1}{|c|}{ Imię i nazwisko } & Liczba art. pras. \\
\hline 1 & Hanna Tadeusiewicz & 15 \\
\hline 2 & Jolanta Chwastyk-Kowalczyk & 12 \\
\hline 3 & Tomasz Mielczarek & 12 \\
\hline 4 & Małgorzata Korczyńska-Derkacz & 10 \\
\hline 5 & Olga Dąbrowska-Cendrowska & 8 \\
\hline 6 & Zofia Sokół & 7 \\
\hline 7 & Grażyna Gzella & 6 \\
\hline 8 & Władysław Marek Kolasa & 6 \\
\hline 9 & Jolanta Dzieniakowska & 5 \\
\hline 10 & Jerzy Jarowiecki & 5 \\
\hline 11 & Krzysztof Woźniakowski & 5 \\
\hline 12 & Jan Bujak & 4 \\
\hline 13 & Dorota Kamisińska & 4 \\
\hline 14 & Alfred Toczek & 4 \\
\hline 15 & Władysława Wójcik & 4 \\
\hline
\end{tabular}

Źródło: zestawienie na podstawie tab. 1-7. 
Wysokie miejsca zajmują autorzy związani z ośrodkiem kieleckim, w którym badania prowadzone są $\mathrm{w}$ zakresie bibliologii i informatologii oraz nauki o mediach: Jolanta Chwastyk-Kowalczyk, Tomasz Mielczarek, Olga Dąbrowska-Cendrowska i Jolanta Dzieniakowska. Z wykształcenia bibliologowie, historycy i medioznawcy łączą swoje kompetencje naukowe, publikując przede wszystkim na łamach czasopisma wydawanego we własnym ośrodku. Tylko J. Chwastyk-Kowalczyk publikowała, poza rodzimym czasopismem (9 poz.) także w krakowskim „Annales..." (2 poz.) i w „Toruńskich Studiach Bibliologicznych" (1 poz.).

Liczne artykuły publikują autorzy związani z Uniwersytetem Pedagogicznym w Krakowie. Od lat pracownicy obecnego Instytutu Nauk o Informacji podejmują różnorodną problematykę bibliologiczna, czyniąc przedmiotem swoich badań szczegółowych książkę, czasopisma oraz inne media. Ten silny ośrodek badań prasoznawczych reprezentują: J. Bujak, J. Jarowiecki, D. Kamisińska, W. Marek Kolasa, A. Toczek, K. Woźniakowski, W. Wójcik. Wymienieni badacze - bibliologowie, historycy prasy, medioznawcy - najchętniej publikują na łamach czasopisma wydawanego przez rodzimy Instytut $^{6}$. Z wymienionymi wyżej dwoma ośrodkami współpracowała Zofia Sokół.

Grażyna Gzella z Instytutu Informacji Naukowej i Bibliologii UMK swoje historycznoprasoznawcze artykuły publikowała w latach 90. XX w. w „Rocznikach Bibliotecznych” (4 poz.), a obecnie w „Toruńskich Studiach Bibliologicznych", z którymi współpracuje także D. Kamisińska. M. Korczyńska-Derkacz (10 poz., w tym jedno współautorstwo), publikowała w czasopismach wydawanych we Wrocławiu (6 poz.), w Kielcach (2 poz.) i w Krakowie (1 poz.).

Na łamach analizowanych czasopism opublikowano łącznie 2094 artykuły, w których problematyka prasoznawcza była podejmowana 290 razy, co stanowi zaledwie $13,85 \%$.

Największy procent artykułów o szeroko rozumianej problematyce prasoznawczej odnotowano w czasopiśmie wydawanym w Instytucie Informacji i Dziennikarstwa Uniwersytetu Jana Kochanowskiego w Kielcach - było to w całym okresie ukazywania się 44,6\%. Najpłodniejszy był okres 20032008, w którym wydawano „Studia Bibliologiczne Akademii Świętokrzyskiej” (67,39\%). Zmiana tytułu na „Rocznik Bibliologiczno-Prasoznawczy” pozornie nie zaznaczyła się wzrostem liczby prac prasoznawczych $(42,45 \%)$, pamiętajmy jednak, że cały numer 2 z 2012 r. został poświęcony problemom polskiego systemu medialnego.

Jak wynika z zestawienia danych w tabeli 9, na drugim miejscu sytuuje się czasopismo wydawane przez Instytut Nauk o Informacji Uniwersytetu

\footnotetext{
${ }^{6}$ Warto nadmienić, że spośród autorów wymienionych w tab. 8 tylko dwóch (J. Bujak i K. Woźniakowski) znalazło się na liście autorów sporządzonej przez A. Cieślikowską przy analizie „Zeszytów Prasoznawczych" (Cieślikowska, 2016, s. 417).
} 
Tabela 9

Udział procentowy prac prasoznawczych w ogólnej liczbie opublikowanych artykułów naukowych we wszystkich analizowanych tytułach

\begin{tabular}{|c|c|c|c|c|}
\hline $\begin{array}{l}\text { Tytuł czasopisma z uwzględnie- } \\
\text { niem kolejnych jego zmian }\end{array}$ & $\begin{array}{c}\text { Lata } \\
\text { ukazywania się }\end{array}$ & $\begin{array}{l}\text { Ogólna } \\
\text { liczba art. }\end{array}$ & $\begin{array}{l}\text { Liczba art. } \\
\text { prasozn. }\end{array}$ & $\begin{array}{c}\text { Udział \% prac } \\
\text { prasoznawczych } \\
\text { w ogólnej liczbie } \\
\text { publikacji }\end{array}$ \\
\hline „Bibliotekoznawstwo" & 1955-2011; & 121 & 9 & 7,44 \\
\hline „Studia o Książce i Informacji” & $2012-2016$ & 25 & 3 & 12,0 \\
\hline Eacznie w latach 1955-2016 & & 146 & 12 & 8,22 \\
\hline „Studia o Książce" & 1970-1993 & 201 & 8 & 3,98 \\
\hline „Roczniki Biblioteczne” & 1957-2016 & 846 & 70 & 8,27 \\
\hline $\begin{array}{l}\text { „Z Badań nad Polskimi Księgozbio- } \\
\text { rami Historycznymi” }\end{array}$ & 1975-2005 & 221 & 5 & 2,26 \\
\hline $\begin{array}{l}\text { „Z Badań nad Książką i Księgozbio- } \\
\text { rami Historycznymi”. }\end{array}$ & 2006-2016 & 84 & 1 & 1,19 \\
\hline Eacznie w latach 1975-2016 & & 305 & 6 & 1,97 \\
\hline $\begin{array}{l}\text { „Rocznik Naukowo-Dydaktyczny. } \\
\text { Prace Bibliotekoznawcze” }\end{array}$ & 1982-1998 & 82 & 28 & 34,15 \\
\hline $\begin{array}{l}\text { "Annales Universitatis Paedagogicae } \\
\text { Cracoviensis Studia ad Bibliotheca- } \\
\text { rum. Scientiam Pertinentia" }\end{array}$ & 2001-2016 & 156 & 39 & 25 \\
\hline Eacznie w latach 1982-2016 & & 238 & 67 & 28,15 \\
\hline „Kieleckie Studia Bibliologiczne” & 1993-2001 & 61 & 19 & 31,15 \\
\hline $\begin{array}{l}\text { "Studia Bibliologiczne Akademii } \\
\text { Świętokrzyskiej" }\end{array}$ & 2003-2008 & 46 & 31 & 67,39 \\
\hline $\begin{array}{l}\text { „Rocznik Bibliologiczno-Prasoznaw- } \\
\text { czy” }\end{array}$ & 2009-2016 & 106 & 45 & 42,45 \\
\hline Eacznie w latach 1993-2016 & & 213 & 95 & 44,60 \\
\hline „Toruńskie Studia Bibliologiczne” & 2008-2016 & 145 & 32 & 22,07 \\
\hline Łącznie we wszystkich czasopismach & & 2094 & 290 & 13,85 \\
\hline
\end{tabular}

Źródło: obliczenia własne na podstawie Tab. 1-7.

Pedagogicznego w Krakowie (28,15\%), a na trzecim - Instytutu Informacji Naukowej i Bibliologii UMK w Toruniu (22,07\%). Z badań prowadzonych przez Władysława Marka Kolasę w 2000 r. wynika, iż 15\% naukowych artykułów prasoznawczych opublikowanych zostało na łamach „Zeszytów Prasoznawczych”, a 10\% w „Roczniku Historii Prasy Polskiej” (Kolasa, 
2002). Autor wskazuje na znaczne rozproszenie artykułów z zakresu interesującej nas problematyki, co dostrzec można i w naszych zestawieniach. Jednak potwierdzają one stałe zainteresowanie trzech ośrodków naukowych (Kielce, Kraków, Toruń) problematyką prasoznawczą. To w nich przede wszystkim prowadzone są badania nad historią i współczesnym obliczem mediów. Warto w tym miejscu zauważyć, że wydawane przez te instytuty czasopisma odzwierciedlają nie tylko prowadzone w nich badania i realizowany program dydaktyczny, ale także znakomicie wpisują się w światowe tendencje łączenia na łamach jednego czasopisma naukowego zagadnień z zakresu bibliologii i prasoznawstwa, np. w „Bertelsmann Briefe" i "Gutenberg Jahrbuch”, na co zwracał uwagę cytowany wyżej K. Migoń (Migoń, 2002).

\section{BIBLIOGRAFIA}

Cieślikowska, Agnieszka (2016). Historia mediów na łamach "Zeszytów Prasoznawczych”. W: Zeszyty Prasoznawcze. Analiza zawartości (1957-2012). Metody, tematy, autorzy. Pod red. Macieja Kawki, Ryszarda Filasa i Pawła Płanety. Kraków: Wydaw. Uniwersytetu Jagiellońskiego.

Dziki, Sylwester (1984). Tendencje rozwojowe polskiego prasoznawstwa (1965-1981). Zeszyty Prasoznawcze, R. 25, nr 2, s. 21-36.

Głombiowski, Karol (1980). Ksiażka w procesie komunikacji społecznej. Wrocław: Zakład Narodowy im. Ossolińskich.

Golka, Bartłomiej (1969). Kształtowanie się wiedzy o prasie w Polsce XIX w. Warszawa: Państwowe Wydaw. Naukowe.

Jarowiecki, Jerzy (1982). Od Redakcji. Rocznik Naukowo-Dydaktyczny Wyższej Szkoły Pedagogicznej w Krakowie. Prace Bibliotekoznawcze, R. 1, s. [6].

Kafel, Mieczysław (1966). Prasoznawstwo. Wstęp do problematyki. Warszawa: Państwowe Wydaw. Naukowe.

Kolasa, Władysław Marek (2002), Czasopisma prasoznawcze i prasoznawstwo w czasopismach. Rocznik Historii Prasy Polskiej, T.5, z. 1, s. 211-235.

Kolasa, Władysław Marek (2013). Historiografia prasy polskiej (do 1918 roku). Naukometryczna analiza dyscypliny 1945-2009. Kraków: Wydaw. Naukowe Uniwersytetu Pedagogicznego.

Migoń, Krzysztof (2005). Bibliologia - nauka o kulturze książki. Nauka, nr 2, s. 49-57.

Migoń, Krzysztof (2002). Bibliologia wobec medioznawstwa: izolacja, komplementarność czy integracja. W: Ksiażka i prasa w systemie komunikacji społecznej: przeszłość, dzień dzisiejszy, perspektywy. Pod red. M. Judy. Lublin: Wydaw. Uniwersytetu Marii Curie-Skłodowskiej, s. 13-18.

Pisarek, Walery (1984). Współczesne orientacje i kierunki badań nad komunikowaniem masowym. Zeszyty Prasoznawcze, R. 25, nr 2, s. 5-20.

Pisarek, Walery (2008). Wstęp do nauki o komunikowaniu. Warszawa: Wydaw. Akademickie i Profesjonalne.

Rocznik Bibliologiczno-Prasoznawczy [online]. [dostęp: 25.04.2017]. Dostępny w WWW: $<$ http://idi.ujk.edu.pl/studia/index.php $>$. 
Sobieszczański, Franciszek (1861). Czasopisma polskie. W: Encyklopedia powszechna Orgelbranda. Warszawa, T. 6, s. 304-353.

Studia o Książce i Informacji (dawniej: Bibliotekoznawstwo) [online]. [dostęp: 25.04.2017]. Dostępny w WWW: <http://bibl.wuwr.pl>.

Tetelowska, Irena (1965). Próba określenia przedmiotu nauki o środkach masowego przekazu informacji. Zeszyty Prasoznawcze, nr 1, s. 3-16.

Toruńskie Studia Bibliologiczne [online]. [dostęp: 25.04.2017]. Dostępny w WWW: <http:// www.home.umk.pl/ tsb/?q=pl/>.

Z Badań nad Książka i Księgozbiorami Historycznymi [online]. [dostęp: 25.04.2017]. Dostępny w WWW: <http://www.lis.uw.edu.pl/badan/?page_id=82>.

Żbikowska-Migoń, Anna (2002). U początków bibliografii czasopism: Christiana Junckera Schediasma historicum de ephemeridibus sive diariis eruditorum (1692). Roczniki Biblioteczne, R. 46, s. 63-77.

Artykuł w wersji poprawionej wptynąt do Redakcji 7 października 2017 r.

Katarzyna Jamrozik

Institute of Information and Library Science

Wrocław University

e-mail: katarzyna.jamrozik@uwr.edu.pl

Małgorzata Korczyńska-Derkacz

Institute of Information and Library Science

Wrocław University

e-mail: malgorzata.derkacz@uwr.edu.pl

\section{ISSUES IN PRESS STUDIES REFLECTED IN SELECTED BOOK STUDIES JOURNALS}

KEYWORDS: Press studies. Book studies. „Bibliotekoznawstwo”. „Studia o Książce i Informacji”. „Studia o Książce”. „Roczniki Biblioteczne”. „Z badań nad Polskimi Księgozbiorami Historycznymi”. „Z Badań nad Książką i Księgozbiorami Historycznymi”. „Rocznik Naukowo-Dydaktyczny. Prace Bibliotekoznawcze”. "Annales Universitatis Paedagogicae Cracoviensis Studia ad Bibliothecarum Scientiam Pertinentia”. „Kieleckie Studia Bibliologiczne”. „Studia Bibliologiczne Akademii Świętokrzyskiej”. „Rocznik Bibliologiczno-Prasoznawczy”. „Toruńskie Studia Bibliologiczne”.

ABSTRACT: Thesis/Objective - Shared origins of book and press studies and similarities in research issues, research methods, research objectives and their place in the classification of 
science disciplines result in the parallel presentation of both research fields in book studies journals. The aim of the article was to analyze the presence of press studies issues in journals published by the institutes teaching book-related professionals in Wrocław, Warszawa, Kraków, Kielce and Torun. The following 7 titles together with their continuations were analyzed: series „Bibliotekoznawstwo” (continued by: „Studia o Książce i Informacji”)”, ,Studia o Książce”, , Roczniki Biblioteczne”, ,"Z badań nad Polskimi Księgozbiorami Historycznymi” (continued by: „Z Badań nad Książką i Księgozbiorami Historycznymi”), „Rocznik Naukowo-Dydaktyczny. Prace Bibliotekoznawcze” (continued by: „Annales Universitatis Paedagogicae Cracoviensis Studia ad Bibliothecarum Scientiam Pertinentia”), „Kieleckie Studia Bibliologiczne” (continued by: „Studia Bibliologiczne Akademii Świętokrzyskiej”, , Rocznik Bibliologiczno-Prasoznawczy") and „Toruńskie Studia Bibliologiczne”. Research method The quantitative analysis was used, where the measurement unit was a journal article (reviews, surveys and polemics excluded) on press studies issues published in selected book studies journals. Results - The research proved that only $14 \%$ of all research journal articles discuss press studies issues and confirmed their considerable distribution. 